\title{
The Consequences of Globalization and Responsibilities: Challenges of Sustaining Development
}

\author{
Zlatan Delić \\ University in Tuzla, \\ Bosnia and Herzegovina
}

\section{Introduction}

Anachronistic simultaneity and 'multiple temporalities' that we live, can easily produce confusion and we already have too much of that, in our so-called global knowledge society. Therefore, we could start with some principal observations. The leading approaches to globalization are those approaches that come from the language and buzzwords of the dominant streams of economic science. Dividing globalization on different dimensions, aspects, lawmakers, opponents, and so on - is also marked by a determined, almost inevitable economic discursive order. Research programs, reconstructions of knowledge systems, liberating perceptions and critical insight of the various researchers - can be expanded or adjusted, especially if we managed to have a balanced relations with epistemological, ontological, ethical and environmental issues but also with other emancipated issues (which were neglected in the 'new knowledge economy'). It is the same situation regarding the social consequences of hegemonic economic discourse of globalization. It is useful to go through the trans-disciplinary approaches and take into account the dangers of 'advanced' recursive, tautological, positivist, linear, reductionist methods that we have been presented with. These methods are very often put forward by dogmatically privileged economists and as such usually don't reflect its own, social or cultural rootedness. However, the crisis of globalization which has deepened over the last decade does not leave much time or space but, in spite of this feverish production of words, "we can hardly move in the consolidation of the concepts, methods and records that would identify and assess globalization" (Jan Aart Scholte, 2005) - the consequences of globalization. We must recognize disparate human experiences of globalization. We tend to focus on the negative consequences of globalization, the ones that upset most people. Globalization is also a symbolic and socially constructed power of appointing, identifying, perceiving, selecting, explaining, and experiencing the world. Its power manifests itself as it presents itself (to act) as a historical inevitability, like some natural force, like gravity. Therefore, globalization is easily converted into globalism - the ideology. According to some social and political thinkers, globalism has become a "strong discourse" - the one that is terribly hard to resist and very hard to dismiss. It's hard, because it has powerful social forces on its side that have already chosen what counts as "real" and therefore they shape 
the world accordingly. Constant repetition and public recitation of the key claims of globalism has the ability to produce exactly what they are appointing (Steger, 2003). Globalization means, first and foremost, global change of language patterns that are in use. Its impact on biodiversity of human language, the discursive order, systems of signification and representation - it is greater from what we are able to see or express at this moment. Positivist approaches to globalization are mainly engaged in various dimensions and aspects of globalization, by encouraging formal classification, uncritical attitude and tabular models of thinking that can easily turn into a dangerous dogmatism. Globalization is certainly multidimensional, but what does it mean? German sociologist, U. Beck drew attention to the fact that "the literature on globalization permeates fundamental controversy." He believes that the answer to the question "what drives globalization forward" has two contradictory responses (that have been divided many times). The first group of authors emphasizes the existence of a dominant "logic", while other authors are working on theories that explain complex, multi-causal logic of globalization. Incidentally, the central theoretical controversy exceeds the horizon of meaning of the word "globalization", because it is often associated with conflicting meanings. At the same time it repeats the historical controversy between Marx and Weber, economic dominance and theoretical pluralism of the economic and socio-cultural approach to the thematic field of globalization sociology. Attempting to push one of the logics into the centre, excludes an important dimension of globalization. Pairing them together (seemingly) and excluding the mutual logic of globalization leads us to the point where various, partial logics of globalization compete with one another. Firstly - we are to talk about the approaches which manage to keep a special dimension and the logic of globalization central. The key authors whom we shall mention here as a common starting point, are the following: Wallerstein, Rosenaua, Gilp, Held, Robertson, Appadurai and Giddens as a common starting point." (Beck, Ulrich: 1999). Privileged economic approaches have imposed their own discursive order and their cognitive assumptions to many other fields of study. These approaches are not sufficient for understanding one of the most important consequences of globalization and that is widening the gap between the rich and the poor. Economic reductionism seriously interferes with, or even prevents, objective study of long-term poverty, structural unemployment, social exclusion and structural irrelevance of certain regions. Key international agencies, such as, the United Nations (UN), World Bank (WB), International Monetary Fund (IMF), Organization for Economic Cooperation and Development (OECD) and World Trade Organization (WTO) - have made many declarations. Such international organizations believe that in this way they will prove dedication to the fight for global justice and solidarity, and that they are against global inequality, poverty, exclusion, etc. Social sciences have the task to demonstrate that such declarations often do not pay enough attention to the cognitive, epistemological-methodological and cultural assumptions. It is on the ground of these assumptions that developed and undeveloped world is put together in the abstract correlation. The economic development criteria, as well as classical and neoclassical measure of poverty, contain significant limitations. These standards have become the subject of dispute among economists such as Karl Polanyi, Joseph E. Stiglitz, Jeffrey D. Sachs, Michel Chossudovsky and many others. The development strategies and policy development is often viewed through the administrative-bureaucratic language, without clear scientific criteria. Development is a complex category. It can mean different 
things to different people. The phenomenon of development, or existence of chronic state of underdevelopment, is not simply a question of economics, nor is it even one of the quantitative measures of income, employment and inequality (Todaro, M. P \& Smith, C. S, 2006). Development is a process that encompasses every aspect of society, putting all the efforts into operation: markets, governments, NGO's, cooperatives and non-profit institutions (Stiglitz). In that sense, generally speaking, it is required to have a better cooperation among economists and other scientists, governments, NGOs, trade unions and public sector. Cooperation is needed in order to avoid economist and reductionist approaches to these problems. However, only when we try and do achieve something like that, we encounter the most difficult theoretical and epistemological dilemmas. One of the tasks that the social science has faced is a critical 'deconstruction' of the wrong approach to the social consequences of globalization. About 80 percent of the world's population lives in developing countries, which are characterized by the low incomes and widespread poverty, high unemployment and low education. Even, the so-called developed countries have perceived their own development problems differently, over the recent years. Economists tend to ignore the social basis of economic activities and rather focus on studying the questions that they themselves benefit from the most. On the contrary, the scientists, generally, have a great responsibility in determining the priorities and objectives of the research they are engaged in. The economists have often pushed increasing social inequality, poverty on the increase, and unemployment in the background, believing that these problems do not concern them. It is similar with other problems, such as environmental degradation, soil pollution, air pollution, water pollution, etc. The critics have warned that these are not problems that are not related to the economy, but quite the contrary. They are deeply connected with the destructive logic of the new global economy. Discourses on globalization from the 90-ies of the 20th century, haven't had any of the implications that it has faced in 2000 and 2001. Over the recent years, confidence in the scientific solidity of neo-liberal economic globalization has dramatically declined and continues to erode. It is undisputed that since the 70ies, and explicitly since the 90ies, the mainstream social sciences began to take the shape of a unique discursive order of globalization, which came into the hands of market fundamentalism, one of the most dangerous ideologies, whose consequences we still continue to suffer. This order is inextricably linked to the institutionalization of what we might call the global politics of knowledge. What we consider by that name, was firstly presented under the signifier of a so-called new knowledge economy. The story of the construction of the so-called new world order and the popularization of various conspiracy theories, arising over the last twenty years, was just a reaction to the cognitive dissonance that arose between beautified language of globalization - and the spiritual and actual misery that has fallen on humanity. The consequences of globalization should be analyzed on the basis of normative requirements for the epistemological unity of knowledge (Masudul Alam Choudhury and Lubna Sarwath Mohammad: 2011) and the principle of accountability which has been neglected for a long time. However, the unity of knowledge is more easily achieved in meta-theoretical discussions rather than in reality. The recent studies have shown that the negative effects of globalization occurred long time ago and that they are primarily associated with the 'rise of capitalism catastrophe' (Klein, 2008), but also with the increasing gap between the rich and the poor. Poverty is a global and regional problem. Poverty is a problem of many communities. The world risk society (Beck, 
Ulrich, 2007) and the crisis of the Western paradigm of the global knowledge society are concerned about the poverty. Poverty cannot be scientifically analyzed, unless we approach it independently and exclude other problems associated with the crisis of 'knowledge society'. The crisis of the knowledge society, tends to destabilize our frame of reference, undermines all stable systems of knowledge, but opens up new research opportunities. The list of problems is long: the crisis of orientation, the lack of public discourse on human responsibilities (in relation to the story about all sort of rights), the commercialization of knowledge, education and research, the growth of social inequality, unemployment, social exclusion, property rights, the right to work, lack of justice, the environment, lack of solidarity, corporate crime, marketing crime, abuse of religion, strengthening the killer identity, violence, lack of corporate social responsibility. The predominance of quantitative techniques in the new knowledge economy requires paying more attention to qualitative methodology and discourse analysis (Sheila C. Dow: 2003) Analyze, for the moment, the very concept of globalization. "The pure concept of globalization," or globalization itself (that what is "transcendentally signified") which we cannot have.

The concept of globalization cannot be included in a scientific theory of globalization. In reality, for instance, we own, or possess, any of the territories. We may appoint it as our property - such property and possession may be in the domain of property rights. But globalization, as such, cannot be possessed. Starting from the logical or philosophical analysis, the concept of globalization cannot be approached from the outside. We humans cannot see it until the end, as if it was from a bird's perspective. Our mind cannot approach it with some divine sight. We need different types of analysis, different epistemologies and different methodologies of globalization. Discursive analysis of globalization can be a useful methodological procedure, if combined with other qualitative and quantitative methods. It is a form of a meta-theoretical, mostly textual analysis, which examines and analyzes the existing approaches, definitions and descriptions of globalization. Discourse analysts and other scientists agree that we need new methods and new literature on methodology (M. Castells: 2000; Norman G. Finkelstein, 2001; Iver B. Neumann, 2001; A. Sen, 2006; U. Beck, 2007.). How was it possible, that a discursive order could produce that what - in the mainstream science - and beyond that, is most often referred to as globalization, and occasionally "colonialism" or "occupation"? Inability to deliver "clean" concept of globalization may be best presented by examples of the inability of non-violent establishment of "pure" culture. Specifically, the idea of a so-called "pure culture" (Zigmunt Bauman) - whenever there was an attempt to implement it somewhere - in reality, has always been associated with the symbolic and actual violence - with the excessive use of force. In this sense, discourse analysis is important because it draws attention that there is no such thing as a pure concept of globalization. Also, we must accept the uncertainty that lies in the issue of a difference between reality which has been understood as a physically given reality and the reality perceived as a social representation (Iver B. Neumann, 2001). After "consuming" the neoliberal form of globalization for twenty years, people everywhere are coming to a conclusion that what is considered to be a globalization is not a good thing. Analysts of discourse seem to suggest that what they said was never sufficiently based on knowledge about what is actually happening in the name of globalization. Discursive analysis that has not given up on the most important tasks of philosophy, such as - the truth, justice and meaning of human existence - would have much to say about the negative 
consequences of irresponsible use of the discourse of globalization. By discourse we mean several things: the language or mode of argumentation, discursive practices, socio-cultural practices and other similar things. However, the critique of the economic discourse, which is not very developed, has just begun to acquire a number of additional, sometimes unexpected meanings. Among discourse analysts, as well as among other groups, the struggle about the necessity of pluralism is never ending. If the notion of a discourse is so narrow that it can only mean one thing, then violence is carried out over a range of other fields of use (Iver B. Neumann, 2001). As we were taught in the Critique of Judgment (1790) by Kant, philosophy does not serve to set infinite expansion, but to set the determination of those limits within which they must firstly reject the prejudices, misconceptions and deviations in order to create some room for understanding the truth as it is. Globalization synonymously indicates a world without borders, and the way we perceive it and believe in that truth will actually prove whether we are able to get rid of our prejudices and misconceptions. In this sense, it is reasonable to assert that there is not such a thing as a conflict-free, referential frame of knowledge about globalization. However, there is a need to try to find the biggest failures and delusions of globalization. The most common misconception of globalization is associated with neoliberalism, or in other words, with the disastrous impact of the neoliberal discourse on economics and globalization in general. But a retrospective critique of the neoliberal discourse about globalization does not mean that we have entered into a post-global time. Unless we rely on a pseudo-logical capitalist trick and the current stage of the overall global crisis and call it a "post capitalist society"- like Drucker (Drucker, Peter: 1993). In one, perhaps crucial sense, the era in which we live is no longer possible to simply designate. We could appropriately call it the age of the anachronistic simultaneity (Derrida). The dilemma on whether the discourse of globalization has too much of the social and too little of the textual or it is the other way around is not just a theoretical dilemma. The fact that the discourse of globalization cannot be separated from what we are talking about - is a sign that it is necessary to draw attention to the consequences of globalization, and not only on what we can or cannot say regarding them. Therefore, discourse analysis, as a very fruitful postpositivist method, is primarily based on the analysis of the irresponsible use of the globalization discourse. There is an enormous amount of literature, texts, programs, proclamations, slogans, pamphlets, flyers, and various movements around the world - they all have something to do with globalization. But the very concept of globalization has become inert. People think too little about each other's social or spiritual connection. Moreover, what we think about globalization and what we say or "conceal" (Wittgenstein) has become more complex. The concept of globalization, which could be socially useful in the 21st century, is not possible to impose as if it was a certain decree. The ruling conceptions of society are mainly based on some kind of discursive imposition of terms. The monopolization of terms has a lot to do with a misuse of terms. However, critical sciences, and global social theories, cannot impose terms that are to be used in each and every society. Instead, the critical science deconstructed those discursive regimes that have a monopoly on knowledge about knowledge, including knowledge of the alleged globalization. Great thinkers, preoccupied with first (or last) metaphysical issues, have an insight into the limits of the human mind, at least in terms of its use. Some have concluded that there is no heaven for concepts (Deleuze \& Guattari), and that all concepts are processed in people's hearts and minds. Thus, the definitions and concepts change over time and space. The terms may be 
used for different things. For instance, a few things - related to marketing - can function well without words. Marketing, for instance, can function well on its own without the discursive analysis of the final effects of their own functioning. But marketing cannot function well without the analysis of financial statements. Criticism of the discourse of globalization cannot separate the effects of the social philosophy and the social effects of advertising discourse in advance. What discourse analysts can do is to warn that it is necessary to constantly keep paying attention to the discursive strategies of speech on globalization. Also, critics of discourse may indicate the need to build some alternative pedagogy of concepts which we use to talk about the consequences of globalization. The philosophical analysis of concepts is very rigorous, "The concept is therefore used as a cover-up of certain, and hence countable items. To perceive it means to have something in your "hand" or a grasp of mind. If philosophy can be defined as conceptual analysis, it would seem to follow that "we have" a sense of the term, or (as strange as it may sound) farm of a farm property. If you cannot provide any conceptual content to the metaphorical characterization of "thinking like properties", then it becomes doubtful, to even say, that anyone has the right to insist that philosophy is the equivalent of a single instrument, namely to the conceptual analysis (Stanley Rosen, 1980). It is also true that the use of "term" globalization is the social problem. We cannot understand the problem of its use only in terms of endless disagreement over the meaning. "People just talk about globalization," as Wallerstein once noticed. The critique of the "empty talk", has suggested that globalization is, above all, concerned with the responsibility for the consequences of what we do. First of all, we could say, for instance, that the post-structuralism, 'deconstruction', new knowledge economy, marketing, feminist theology etc - if we treat such discourses as separate research areas - are not sufficient to radically deal with the problem of the negative consequences of globalization. The critics of the theory of economic development have observed and noticed that science, government and marketing is based on the system of knowledge about man, society and nature, for which they claim to be valid everywhere and for everyone. Since knowledge has successfully removed all traces of their own origin, time and environment, it does not belong anywhere, and therefore can penetrate everywhere. In a sense, (1) mechanical causality, (2) bureaucratic rationality and (3) the law of supply and demand are the rules that have been cleared of any attachment to a particular society or culture. No wonder that, throughout the history, we encountered subversive movements that have advocated a simple lifestyle and asceticism. The rich society today represents a threat to the survival of the planet, and their material wealth is actually an indicator of their cognitive misery. From its earliest impressions of the 60 -ies of the $20^{\text {th }}$ century the notion of "globalization" is used in both popular and scientific literature to describe the process, state, system, power and time. Due to these conflicting marks and the different meanings that they imply, their uncritical use is often vague and misleading. For instance, combining the process and the state encourages the creation of circular definitions which explains very little (Steger, 2003). Concluded from the previously mentioned, it is possible to conclude that the uncritical use of globalization causes confusion. Also, it suggests that scientists should turn to criticism. Criticism is an important element that makes the science function. Criticism could eliminate, or at least minimize confusion about globalization, which contributes to the increasing presence of essentialist, uncritical literature. The term essentialism implies a form of discursive order which cannot review the social implications of their own functioning. In the 90ies, neo- 
liberalism has successfully presented itself as a force that helps the process of modernization and dynamism, accusing the labour movement, left wing and labour union for conservatism and hostility towards technological advancement. At the same time, the faith in progress and development started to shake. The period from 1992 - 1995, was marked by a so-called "humane resettlement of people" plan in the name of the implementation of the so-called "clean and pure cultures of ethnic territories" (in the government of Serbia during the Milosevic regime, and then in the government of Croatia, during the regime of Franjo Tudjman). The plan was founded in the Serbian Academy of Arts and Sciences in Belgrade. What came next was the misuse of religious officials and the church, with the homogenization in the background as well as mobilization, and organizing for the purposes of an aggressive war. The implementation of the previously planned forced displacement of population, ethnic cleansing, deportation (genocide) happened on the territory of the multicultural and internationally recognized state of Bosnia and Herzegovina. Since the end of the WW2 in 1945, it was stated all over the Europe that genocide is never to happen again to anyone, anywhere. (This statement probably meant that it cannot happen again - but it did). After that, an act of plundering occurred in the name of free markets and democracy mainly through privatization. It was a rough ethnic privatization of the assets of the working class, which was created in the long decades of hard work. The negative consequences of neoliberal globalization, and the social effects of free markets and privatization, have been more salient than positive ever since. Firstly, the power and influence of individual countries (or even entire regions), particularly of the developing countries, are getting weaker. Secondly, the risk of instability in financial markets are getting higher (as seen in the 1995 Mexican crisis, the 1997 Asian crisis, crisis in Turkey and Argentina in 2001 and crisis in Greece, Italy, Spain, Portugal and many other countries). The global financial crisis is related to a whole network of others: global, regional and local geoeconomic, geopolitical, trans-cultural and orientation-related crisis. The crisis has been associated primarily with the cognitive and social-epistemological crisis of the very idea of knowledge society, with a crisis of economic, political and trans-cultural identity of the EU, but also with the encouragement of the Balkan neo-fascist genocidal fundamentalism. The most obvious example of the crisis of democracy is the negation of the idea of cosmopolitan living together on the ground of the European continent. At this point we have an institutionalized racism, created by an international mistake (or with an intention), such as: geopolitical act of installing a genocidal formation of Republika Srpska in the heart of Europe. It happened on the ground of Bosnia and Herzegovina, an internationally recognized state. Institutional reward of ethnic cleansing is in favor of the monstrous idea of achieving the so called "pure culture", as was formulated by Z. Bauman. World financial crisis is intertwined with the unintended consequences of market fundamentalism, and takes the form of international geo-political and geo-economic crisis which threaten to undermine peace in the world. The fact that capitalism has become a global system makes it also sharper and a lot more unbridled (Kagarlitsky, 1999). The theory of globalization has suffered some criticism over the recent years. The major objections were related to the fact that the neoliberal globalization of the world of life entailed excessive dominance of epistemological fundamentalism (an example is the predominance of commercially motivated actions such as "Quantifying Quality" even in the areas of education, or human health). In general, with the help of the new knowledge economy, neoliberal globalization contributed 
to the spread of essentialist, monistic and internist methods and procedures of knowledge. The economic dimension of globalization, determines all the other dimensions, especially by emphasizing the commercial picture of globalization. Such a picture mostly suited multinational companies, or interests of a handful of individuals. They get (and use) an opportunity to usurp and almost infinitely expand its social, cultural and political power. Commercial picture of globalization is, in essence, one-dimensional and reductional. It encourages consumerism, infantilism and social irresponsibility, and enables the formation and cultural reproduction of one-dimensional structure of personality. Therefore, commercialization, in all aspects, especially in the terms of commercialization of knowledge, has long-term negative consequences for the wider interests of the public good of a huge number of people. The new knowledge economy is not value neutral, but on the contrary, it is completely imbued with the capitalist strategy of commercializing the idea of knowledge. In this sense, it is (or can be) cognitively very limited. In fact, the stylization of the economic ideas of knowledge is characterized by the absence of reflexive, spiritual, emancipated multicultural, critical, pluralist, and post-colonial experiences of what we call a global reality. In contrast to the reductionist conception of the idea of knowledge, which is promoted, expanded, and distributed and upon which they impose commercial discourses and institutions, there are many sets of critical approaches to knowledge. These approaches do not belong to the mainstream science and are not rooted in privileged institutions of knowledge and power. They are characterized by being open towards different experiences of globalization, pluri-perspectivism, and multi-cultural epistemology. Also, insisting on a higher principle of social responsibility of science is not uncommon for the critical approach. The critical approaches are based on differently perceived holistic philosophy of knowledge. Such approaches represent the unity of science and universal environmental ethic. The results are reached in equal communication, which can consist of completely different and even disparate experiences of imposing neo-liberal concept of globalization. The critical approaches to globalization are not even nearly unambiguous. The differences come from there because such approaches include deepening of the main currents of post-positivist emancipated, hermeneutic, phenomenological, feminist, deep-ecological, and post-normal research, practice and experience. Without attempting to impose definitive conclusions, all of these critical approaches have something in common and that is that they recognize the value of open and dialogical forms of knowledge which can be put in the service of the common good and the welfare of most people. Analysis of the discourse of globalization, as a post-positivist method of knowledge, consists in the fact that we pay attention to the archeology (Foucault) of the language of globalization. Also, again and again the less visible, the underlying assumptions and metaphors are being analyzed which contribute to building a particular argument. Language of globalization is not seen as an unproblematic, conflictfree system of concepts that refer directly to things and phenomena. It would be right to say that the focus is on the construction of social meaning, and that language is analyzed as a discursive order (specific socio-semiotics spheres) and it is a part of the overall social system. This order has its own rules and its own logic that dictates, and reproduced again and again the reality that we are talking about. In this sense, critical discourse analysis of globalization reveals a remarkable power and consequences of the appointment, because the way we name things, dictates the meaning that we are to ascribe to phenomena and how we evaluate them. The symbolic and the real impact of globalization on people and nature, is 
huge. Thanks to M. Foucault, we know that knowledge and power are connected. Nowhere is this more evident than in the symbiosis of the so-called "new economy of knowledge" and the politics of knowledge in the dominant trends of economic science in the West. The new knowledge economy, from the 1990s, based on the ideology of market fundamentalism and the technological determinism, was linked with the global political economy of power.

The new knowledge economy has solved a fundamental epistemological problem of establishing knowledge - or its own foundation, in other words - by declaring itself to be a knowledge-based economy. Knowledge is very simply defined as an IT collection of useful information. The whole field of ontology or metaphysics of knowledge, new knowledgebased economy, has reduced it to "information." The rare warning that knowledge cannot be reduced to information, has not met with the approval of the mainstream economics. For the new knowledge economy to avoid being placed in an air-free space, it was necessary to view society as if it was permeated with knowledge and that explains the quick change of the title into an information society of knowledge (and skills.) Relationship between "knowledge" and "skills" were able to be set up completely free, since society is reduced to the market, and all social relations could be established on the model of market relations. The critical expression of "market fundamentalism", which started to be used after some time, and which wanted to warn that society cannot be reduced to the market - came too late. The only fundamentalism, which the global public is constantly "being bombarded with," is another form of fundamentalism - Islamic fundamentalism. As formulated by Eriksen - on 11th September in 2001, the world was hit with one stone and thrown into an uncomfortable and paranoid time, in a war without front lines, a conflict, without limitation, with a clear beginning, but with an uncertain end. Cues for the globalization of the 90ies were the openness, freedom of flight, the Internet and the aircraft traffic on the increase. Cues for the following ten years of globalization are AIDS, threats, controls and the police state. We could cite various examples of long multiple-decade effects of U.S. foreign policy but it has already been done and nothing is accomplished. It is therefore worth quoting Eriksen when who says: "All the intellectuals who do not want to be idiots when it comes to a scenario of a conflict between" the West "and" Islam ", must focus their main priority on the strategy, which reduces the mutual enemy forces, now" (Thomas Hylland Eriksen: 2002). If we are to understand suicide terrorism, we must carefully examine the wider socio-political context in which it occurs. If we are to mention a quote that explains the spiritual poverty of companies, when it becomes trapped in fundamentalism, then here is one: "We live in a fundamentalist world because the fundamentalists have such a strong impact on so many of our institutions - religious, political and economic. I am not saying that there is a global conspiracy of fundamentalisms. Fundamentalists of one area are not necessarily in agreement with the fundamentalists of another - and so that can often lead to a turbulent, mutual disagreement. What is particularly evident in the field of religion is that Christian fundamentalists reject the claims of Islamic fundamentalists and vice versa. Each side claims that they are the only ones who "know the truth," which was discovered only, solely and exclusively to their prophet. There is no disagreement in this part of their faith. The definition is that monotheism cannot stand the rivalry... Religious fundamentalism is exclusive by nature - either you are within the circle of devoted believers, or you're against them (S. Sim, 2004). It is more or less the same when it comes to market fundamentalism, when it mastered the world's economic, political and educational institutions - as it 
happened after 1989. Market fundamentalism is a thoroughly documented phenomenon in world civilization (the term was made up by George Soros). Some commentators find the International Monetary Fund and World Bank to be a threat to the world peace and harmony. According to Sim's observation, an Islamic scholar Akbar S. Ahmed was one of the first to draw attention to the negative effects of the policy of the IMF and World Bank toward the Third World countries. However, it is not particularly important who among the scientists drew attention to that what many other people noticed as well. Today, there are many who will speak of market fundamentalism as a dangerous catalyst of other fundamentalisms. It is possible to specify a number of examples of the negative consequences of market fundamentalism (Africa, Russia, Southeast Asia, Argentina and so on). They all witness to what can happen when the free market economy (it turned out that not even some of the most developed countries followed the rules of the very policy that they themselves imposed), is imposed, without any alternatives, on the countries that lack the necessary social and political structures that could enable this program to be implemented. The fact that in the circles of media, political, scientific and other public discourses, we can talk about a variety of different fundamentalisms often remains unnoticed since there is a tendency of selecting our perceptions. The recent American philosophy text, for instance, is a good example of how it is possible to work on a symbolic extension of the social conditions for the creation of a global liberal democracy with the use of ironic critique of "methodological essentialism". There would be a minimized possibility of humiliation, glorifying violence or a violent attitude of people towards one another (Rorty, 1989), in such a society. It is true that the best way to get the people to suffer constant pain is to humiliate them, display the things that they value the most as useless, superfluous and without force. 'Imagine', says Rorty, 'what happens when the child's precious things things which help the child to create fantasies and also things that differentiate that child from other children - to be re-described as "rubbish" and "rejected". Or what happens when you make fun of such things, in relation to other things, that are in the possession of a wealthier child. Something like that is probably happening in a primitive culture when it gets occupied by another, which is more advanced. Occasionally, the same thing happens to illiterate people in the presence of the intellectuals (R. Rorty, 1989). The comparative study of various types of fundamentalisms is a sign that the central problems of globalization and the global knowledge-based society deeply imbued with pragmatic and socioepistemological issues. (A. Sen, 2007; T. Coady and M. O 'Keefe, 2002; E. Hobsbawm, 2007; Monbiot, 2004.) Here we come up with a series of paradoxes. The central paradox is that the new knowledge-based economy, which is basically a part of a global knowledge society, is deliberately getting rid of its own self-reference, while developing its advanced vocabulary. In fact, it does not call for an epistemological tradition of philosophy of knowledge, but it builds its own philosophy (the so-called business philosophy) and its own ethics (so-called business ethics). Is business ethics as a discipline, meant to be in the service of corporate interests and to what extent? Is it meant to be a servant to a new knowledge based economy? Professors of business ethics have recognized it and stated that: "Teaching on the course of business ethics can be a difficult and demanding task. Many students come to study business economy in order to become rich or to at least try to make a good living. They believe that the capitalist business world is some kind of a jungle where only those with best skills (and most competitive ones) manage to survive. In the view of this light and 
regarding the business, ethics is far more than just the moral action in other parts of a human life. According to one of the American, "Business ethics is the ethics of poker," Bluffing and cheating is allowed in poker. (Norman Bowie, 2007). After 2011 years, the discourse of globalization is still inherently controversial and completely at the service of the power that it determines. The radical power produces its own impotence because it causes even more powerful one - a radical opposition to power. The greatest power of globalization is placed in its very discourse, the discursive order and its institutions of knowledge. Power is therefore connected with the knowledge and has always been rooted in the policy of nomination of that what we build a world of meaning on or even knowledge itself. Only the name you give determines what a thing is or what it may become the future. Each policy of appointment also means the demonstration of certain power. However, in its ultimate effects, which are manifested in the impossibility of reaching transcendental signifier - the politics of appointment reveals its own impotence. At the end - what we learn from poststructuralism and deconstruction is that - the name never refers to the thing itself. The politics of appointments fully identifies words and things, and therefore invokes its own discursive failure. After twenty years of fruitless debate over globalization, we have entered a new era of dogma (S. Sim, 2004), which is more destructive than the previous one we had. Preferential flow of the Western science claim that the world is making a progress and it is developing, as a whole. It has been constantly pointed at the fact that we live in a free and democratic society of both creative and equal opportunities. We have been told that we live in the era where science, technology, innovation and creativity rule and we live in a global knowledge society. It is true for those who have access to all of this, but it is a lie for the biggest number of people living on the planet. Many people suffer from the consequences of poverty and have been humiliated. We live in a world of fear, in a destructive world of unwarranted violence against man and nature. We are trapped in the nets that we ourselves have forged. The future causes us to tremble. We flounder in our own self-deception and forget "the oblivion of Being" (Heidegger). We are in the networks of a meaningless production of fear of another man and of a continuous media production of mortal enemies. Civilization has reached a critical stage when what is called a civilization turns out to be the greatest enemy of civilization itself. The responsible scientists have warned that we have entered the era of dangerous fundamentalist ideas and ideologies - the world risk society (Beck, 2007). We live in an irresponsible, dissolute, consumerist, foolish, barbaric society. The society which has been described by pessimistic authors as a controlled society, society of surveillance, violence, mistrust, manipulation, and organized corporate and media control over the body, mind and emotions. We are exposed to strong biases, stereotypes and unseen - an almost unprecedented violence. Many authors assume that something has gone wrong. That, what the world history perceived as wrong, is linked to the modernist, colonialist, imperialist and neo-imperialist strategies in many ways, as well as with the current global policies of a well-known spreading of ignorance. The colonialist strategies of developing and advancing the notion in the past, was recognized through the grandiose metaphysical systems (so-called absolute knowledge) from the arsenal of great philosophies in the West, for instance, in objectively idealistic strategy of constructing a so-called scientific "views on objectivity" (Hegel). What seems to be the problem and the biggest misunderstanding in different discourses on globalization? Global politics of appointments carried out in the signifier of the globalization discourse, wants to impose a black-and-white, 
bipolar, murderous global perspective on the identity of the world, everywhere. Maalouf, for instance, speaks of the "murderous identities" precisely in the context of globalization and the need for belonging. A serious misunderstanding of religions - if such a thing exists is also affected by this deadly logic, resulting in a global turmoil in our hearts and minds: "Such turmoil can be expressed in the following way: Is globalization just another word for Americanization? Will not its main effect be to impose a single language throughout the whole wide world, as well as the same economic, political and social system, the same lifestyle, same scale of values that they have in the United States? (Maalouf). Indeed, it is worth thinking about the deeper, epistemological, social and other reasons why, the view that the totality of the phenomenon of globalization is a deception, is expanding more. Yes it is a "dust thrown in people's eyes" (Wallerstein, 2003); The domination hidden in Trojan horse, or is it that the globalization has opened a representation of the impossible, yet possible, strategically guided special war being waged between the different, complementary in essence, competing, self-injurious, and therefore false fundamentalism causing immense damage to all of us. Discursive order of the privileged image of globalization tends to get organized and selected through the exclusionary categories, such as: "we" - "they", "our" - "their", "good" - "evil", etc. After a series of an "impossible / possible" event - which happened - after 2000 - a new army of experts emerged out and imprinted new, beautiful words in a receptive canvas of our post-traumatic consciousness: the "clash of civilizations"- they wrote:"axis of evil", "Islamofascism", "Homeland security"(Klein, 2007). We encounter a difficulty by trying to explain the history of the ideological crusade that reached its maximum through the radical privatization of war and disaster. This difficulty, as Naomi Klein explained, is about ideology: an ideology changes its shape - and changes the name and identity forever. Friedman, for instance, called himself a "liberal", while his American followers - associating liberals with taxes and hippies identified themselves as "conservatives", "classical economists", "supporters of free markets" and, later, fans of "Reaganomics" or laissez-faire economics. In most parts of the world their beliefs are called "neo-liberalism", but also the "free trade" or simply put, "globalization". Only during the second half of the 90ies, did the intellectual movement, led by the leadership of brain trust, which Friedman has linked with, - Heritage Foundation, Cato Institute and American Institute for Entrepreneurship - proclaimed to be "neoconservative", thus presenting a worldview that is in the service of corporate plans, he clamped down all the strength of the U.S. war machine. All these incarnations have affection programmatic trinity in common: (1) removal of the public sphere, (2) full liberalization of the corporation, and (3) radical cuts in public spending. The only problem is that none of the names of various ideologies sound appropriate enough (Klein, 2007). Globalization can act on the behalf of more than one name. All of these names feel free to fluctuate in different discursive fields and gray zones of questioning of knowledge economy, power and useable information. Perhaps the biggest fallacy of the popular (supportive) globalization image is the shallow faith in the alleged clash of civilizations. In his book How Soccer Explains the World: An Unlikely Theory of Globalization, Franklin Foer puts it very nicely that some people "are experiencing football deeper than religion." Of course, this is referring to the fans. What do the fans do? They are cheering. Supporting whom? The answer is "ours". They are against the opposite team, against "their team". It's always "us" and "them", "we" against "them" - "them" against "us." It is a very simple logic. However, it is completely wrong, as 
well as a pamphlet on the Clash of Civilizations. Starting from the game - through the war to the fight that will last until the Judgment Day or Death? The power of militant pamphlets lies in the fact that it is primarily addressed to the masses, mental "fans" (who believe in them) and not thinkers or analysts of discourse. The world is not the same to someone who reads certain authors such as, for example, Derrida and Chomsky, compared to someone who does not read them and still believes that violence in stadiums or around the stadium is justified. In violence, or even wars between fans, such as Arkan's (Franklin Foer wrote about him) it is required to have the highest sense of one's individual existence. The media are in the service of interests of powerful men. The media does not educate people that selling sport players is a postmodernist version of the colonial "slave trade", or selling out the football matches so the sport betting could profit on the present global, regional and local levels. Excited, loud voice of sports commentators (with too much shouting) never makes it known to fans that their cheering support is hopeless in such situations where the result has been pre-set: They do not say that their cheering is pointless and humiliating. Supporters see the ball and not the game that is being played. Fans are the ones cheering and not the ones thinking. The first sentence by D. Mabot written in his ethics is: the man has a responsibility to think. Of course, opinions cannot be prescribed by a decree - such as Bologna. This global collective "we", that universal, indispensable deputy is present whenever we talk about universal human rights or duties, something that we will discuss later in the text. In some contexts, globalization can mobilize the masses to the level of arising fans' passions and emotions: as a particular flag, motto, or song. It can be a common buzzword, a rhetorical tool for something else. Today's mass media - often with the help of marketing, systematically distorts our view of any of the really important issues such as global democracy, justice, solidarity and survival of a mankind. That, what is specifically done in the name of globalization, can therefore take any name or form: civilization, culture, freedom, democracy, free markets, technology, new economy, information, knowledge society, the informal market, informal economy, and even so-called war against terrorism: "When the market goes too far in dominating over the social and political outcomes, opportunities and benefits of globalization are spread unevenly, concentrating power and wealth among a selected group of people, regions and corporations at the expense of the majority" (Steger, 2003). In a very concessive way, it is possible to distinguish between the three basic views on globalization - neo-liberal, reformist and radical:

1. Neo-liberalism in the market recognizes "the fundamental strength of a human benefit, freedom, democracy and peace." That's why the state border should not and must not be an obstacle "to an efficient allocation of resources in the world economy", and in the same way a state must not intervene in the economic sphere - the "Control of globalization" should be left to the global markets, which should work without any formal restrictions. Neo-liberalism as the dominant conceptual and policy framework should encourage governments and multilateral institutions (IMF, WTO). Multilateral institutions advocate privatization as a measure to reduce state ownership of productive resources and they suggest that states work on reduction of expenditure, guaranteeing social well-being, thus opening up the possibility of market mechanisms in pension and health care policy as well as in other areas of social security.

2. A reformist approach generally accepts globalization and its driving forces (capitalism and modern technology in an attempt of proclaiming the global social democracy, rational application of knowledge, market ...), but it also requires some corrections, and 
is committed to the implementation of global social democracy. The foundations of this approach can be seen in Keynesian economics, New Deal, Great society in the U.S. and Western European welfare state. Reformism recognizes the strong drivers of social welfare in capitalism, but believes that the public policy plays an important role in achieving positive results. On the one hand, wild capitalism produces personal, social and environmental injustice, and, on the other hand, the global market can fail. Therefore, it is necessary to introduce corrections in the form of political intervention of public institutions. The reformers, therefore, do not believe in "immaculate" nature of capitalism, but instead they advocate the measures to promote its positive and suppress its negative potentials (e.g. antitrust measures to limit the power of corporations). Some believe that the national strategy is not an appropriate tool of managing global capitalism and therefore advocate for the global public policy in which supranational institutions would play an important role (rules of conduct of global companies, global environmental regulations ...). Thus, as some authors noticed, the IMF should create a mechanism for the establishment of greater stability and fairness in global financial markets and global institutions should pursue programs that would improve the state of the global economy of the disenfranchised.

3. A radical approach advocates reversal of globalization, or its continuation, but in a different structural basis. It is possible to distinguish between two types of radicalism: a) a reactive traditionalism and b) proactive radicalism. The first one is in favour of preventing globalization and going back to the idyllic, autarkic pre-global state, because it seems that de-globalization is the only way to restore economic security, ecological balance, cultural integrity and democracy. These and similar ideas are usually represented by environmental radicals, but also by economic nationalists and groups that support going back to religion. Proactive radicals accept the continuation of globalization, but want to see it on different grounds. A wide range of diverse actors and movements such as worldly movements of workers, women, the oppressed by postmodernist critics of contemporary society belongs to this group. Considering that radical approach to globalization failed to achieve a stronger influence on the official institutions, and neoliberal reformist approach, they still continue to fight for total domination, outlining an old controversy about the extent to which states (in terms of nation-states) may interfere with the functioning of markets. Here we should point out that the last three decades - and the level of international relations - was marked by a significant predominance of the neoliberal approach. Among the different concepts of globalization, there are those that oppose her and have other tendencies and processes which are equally strong and far-reaching (Kalanj, 2001; in Marija Geiger Zeman and Zdenko Zeman, 2011).

For instance, Benjamin R. Barber recognizes not one, but "two-axle principle of our time": "globalism" and "tribalism." According to the interpretation of Roland Robertson, Barber represents the notion of globalization as a sharp opposition to the world of the local, but Roland Robertson rejects this approach. Instead, he advocates the concept of globalization, which includes a "simultaneity and interpenetration of what is conventionally called the global and local" (Robertson, 1995). To emphasize this close relationship and interaction between global and local further, Robertson reaches for the concept of glocalization, which was made up, according to the Oxford Dictionary of New Words (1991), in order to combine global and local mix in a way that will allow them mutually beneficial intermingling. 
According to another dictionary (Oxford Dictionary of Sociology), the concept of glocalization means "global localization" or "the process through which global processes, such as the activities of transnational companies, result in the preparation of local, specific goods" and "Communicating specific information back into the global system" (Scott \& Marshall, 2005). According to the Oxford Dictionary of New Words, the idea of glocalization emerged from the Japanese term dochakuka (derived from dochaku "live in their own country"), which originally signified agricultural principle of adapting one's farming techniques to local conditions, so that the Japanese business practices would take them and reinterpreted it as a global localization and global approach adapted to local conditions (Robertson, 1995). Robertson states that global is not opposed to the local, but on the contrary, states that "what is often meant by the local, is included within the global" Discursive form of globalization, which tends to provide absolute power for itself only causes a radical resistance. The very existence of globalization - no matter what you meant by this opaque name - will depend on its radical transformation. Globalization does not recognize who her true friends or true enemies are. If we could imagine philosophy to be a friend of the concepts, then globalization, as an absolute discursive order can easily become an enemy in terms of freedom and opinions. Driven by commercial and corporate interests, marketing seems to be the only heir (prematurely discarded) of philosophical wisdom in the Western world today. Connecting the spiritual sense of philosophy and the consuming interests of marketing is logically impossible. The movement for global justice has developed thousands of websites, magazines, videos, pamphlets and books, which may serve as competing sources of information on many global issues. Marketing is a recent invention, an innovation. It is the manifest of the absence of thought - and a pure negation of philosophy. Marketing is a privileged place for the control of our mind, body and emotions; a holiday of seduction: an organized deception, lie, deceit, illusion, delusion. Marketing has declared itself to be a science. The manifesto, that they have agreed on, could be interpreted as a symptom of profound crisis of identity in Western science, but also as the sign of the great issues of free thinking and responsibility at all. Marketing itself has twisted and subverted science, metaphysics, ontology, epistemology, hermeneutics, aesthetics, ethics, ontotheology and so on. Marketing has used its big lies and illusions, from all sides, to occupy the language of the new knowledge economy. Marketing has turned time into money, space into the market, the man into the consumer and the service user (e.g. patient = client, or student = 'satisfied' customers), and the thinking into a lucrative calculation. Human beings are turned into "human resources" - the means for achieving goals created by the marketing, capital logics, and corporation. For instance, in some schools in the Balkans it is now evident that they have introduced a subject called consumer rights. That way they teach children from an early age, about consumerist mentality. They encourage the consumption, wastefulness, branding, stereotypes and irresponsibility. They only superficially speak about the rights, needs and desires of consumers (e.g. The Universal Declaration of Human Responsibilities / die Allgemeine Erklärung der Menschenpflichten/ is not mentioned). An act of discrimination is present, since the children are forced to differ mutually. In some schools, children are even physically separated into different classes (a so called phenomenon of "Two schools under one roof "), sometimes just because they have a differently written or pronounced name or surname that a child accidentally inherits (from someone else) in their first or last name. Under the influence of right-wing Cetnik's politics 
in Serbia, some politicians in certain parts of Bosnia and Herzegovina from 1992-1995 committed a large 'ethnic cleansing' of non-Serb population. Today, with the great help of the international community, they represent a globally dangerous idea that co-existence of people of different ethnic or national origins is not possible in reality. International support of such ideas can inspire new genocidal plans and projects, and lead to new ventures and new ethnic cleansing genocides.

The responsibility of intellectuals, journalists, media, citizens and world democratic era of globalization is vast. The commercial media has been filled with emotional and social intelligence of children and adults as well as frequent advertisements which are constantly displaying quick and moveable images. Commercials can be effectively advanced and they can improve the processes and the minds of children, and sometimes completely eliminate the need for complex cognitive processes of personality learning and maturing. Advertisements are not limited by the boundaries of time and space. Advertisements urge people to desire what other people want them to desire. They ignore the deeper-based natural cycles of day and night. They ignore the harmony of life and social world. For instance, large illuminated advertisements in cities affect the living beings, because they amplify light pollution of the environment. Globalization of the media, as well as the use of new media, can result in unpredictable consequences. Therefore, it is generally wrong to speak about globalization only in terms of positivist, advanced categories, or in only negative terms. Almost everything that comes in the name of globalization, comes along with something else, in the name of something else - the discursive order of the new economy of knowledge occurs, for instance, as strategic management, the manipulation of resources: time, space, identity, or career. The new knowledge economy is becoming a political economy of a signifier. It is a deeply politicized discursive and visual production and consumption of signs, pictures and information. And what we, at some point, generally can address as a piece of information or knowledge appears to be something else, at another point. The very discourse of globalization has turned into a very important item intended for public consumption (Stegar, 2003). Globalization was supposed to mark a single borderless world but the reality proved it to be more seductive than capitalism and communism. Globalization has linked the goals and means, and it is often that means determine goals. There is battle against the negative consequences of globalization because the man has become a mere tool of corporate interests and goals of capitalist globalization. The statement on the inevitability of globalization depoliticizes public discourse on globalization. The ideologues of globalization (intellectual advocates of globalization) are those people who deny or minimize the negative consequences of neoliberal forms of globalization (globalism). They argue that globalization is an inevitable force of nature like time or gravity. They claim that people only meet the principles of the world market, and that alone these laws require the elimination of any regulation or control of globalization trends. Thus, the ideologues of globalization of the 90ies could convince a large part of the public that the state has become a surplus. It has been written that our concept of society is no longer useful, because there is globalization to replace it. Justin Rosenberg was among the first who has used an immanent analysis to show that this view is contradictory and untenable. The invisible hand is not so invisible. Every progress of science leads to new, hidden dangers. Let us consider how scientists have assured the public that genetically 
modified crops is actually safer than the cultures obtained by traditional methods. It was assumed that scientists can alter the genes responsible for desirable traits, and leave everything else intact. Although many scientists have believed in that story, it turned out not to be true. Firstly, the insertion and activation of new genes significantly interferes with the entire genetic system of an organism. Nobody knows what the inadvertent damage will be caused to the genome. Fish that have been modified to grow faster were deformed and died before their time. Genetically modified maize contained allergens and regularly polluted crops of other varieties of corn. When the researchers in Germany have tried to reduce the percentage of sugar and increase the percentage of starch in the potatoes (by using genes from yeast and bacteria), they have actually reduced the percentage of starch. These and many other examples show the ignorance of the potential harmful effects of genetic technologiesThus, the paradigm of world risk society draws attention to the many things we do not know and we cannot know that our safety, as individuals, societies, species and environment, will be threatened. It is interesting to see just with the progress of socalled global knowledge society, that we live beyond the normal, at the time post-normality. Post-normal science started to realize that we need a new form of science. The old idea of science, where empirical data lead to true conclusions, and scientific reasoning lead to the correct policy is no longer convincing. The way forward must take the form of dialogue that is based on the recognition that there is uncertainty and ignorance. Such a conclusion also strikes at the heart of the governing narrative that the "new knowledge-based economy" is actually based on the epistemological unity of knowledge and responsibility for the results of technological discovery. Also the definitive scientific diagnosis of global capitalism contained in tautological new management buzzword, is that we live in a global society of knowledge (and skills). The combination of ignorance and uncertainty on one hand and political change in science - including its financing, commercialization, complex security issues and new ways of knowledge production, on the other hand - means that science cannot function in "normal" way. Post-normal science type of analysis that occurs at the point between science and politics can include anything - starting from the scientific study of politics to public dialogue about the quality of these studies (Z. Sardar \& Borin Van Loon, 2001). Sustainable development of global, regional and local communities is not possible if you are in the mainstream of economic science teaching uncritical recycling of "cloned textbooks" (Ritzer, 1996) of management of humanity that resemble the egg as an egg. Accounting of the 21st century must not only be creative but if we want it to be sustainable, at the level of school education of accountants, it must be accompanied by normative, environmental and ethical principles. Environmental and ethical literacy prohibits the abuse, falsification (hairdressing) of accounting reports in its principles. Econometric measurement of progress, growth and development - whether of the local, regional or national community - should not be based on pseudo-logical basics of self-delusion. Selfdeception is defined as (1) activity to avoid recognition of self unpleasant reality and (2) a mental condition that results in ignorance, false beliefs, unjust attitudes and emotional distortion. You can lie to yourself and to the systematic use of (unconscious or partially conscious) tactics such as denial, repression, rationalization, conversion (to oneself or others), selective attention to evidence that suggests what we want to believe and selective ignorance of contrary evidence. Such tactics help us to explain the complicated thinking of highly intelligent managers who either try to apologize or attempt to justify their own 
crimes behind the white collar ("Nobody is really hurt"), production of harmful products ("If we did not do it, someone else would"); exploitation of employees ("Business is business") sexual harassment ("They were free to reject my offer"), racism ("they are all like that"), sexism ("I got the job only because of affirmative action"); An act of ignorance towards yourself and your family ("I'm a workaholic, just committed") and the neglect of the environment ("just doing my job to increase my profits"). Sustainable development in the broadest sense, involves environmental sustainability and intergenerational solidarity. This means that future generations that come after us are not deprived of the possibility to live a life that is worthy. The environmentally-conscious concepts of a GDP (Gross Domestic Product), is also appointed for an instrument that reflects the economic fundamentalism. It measures the wrong things, which lead to erroneous conclusions and faulty economic and world politics. The fundamental objection is that the first version of the GDP made during the Great Depression and it was used by Keynes's economic managers. It came very close to its present form during the WW2, when great efforts were made to maintain high production. Kaynes' associates could not even dream of that production - the very notion of production - soon to be altered. This is not just about consumption, in accordance with the consumerist post-industrial capitalism, became more important than production (G. Debord, P. Bruckner, J. Baudrillard, D. Harwey, F. Featherstone, M. Castells, H. Hromadžić). The destruction of families and communities, and devastation of nature and natural resources in the formal vocabulary of the new knowledge economy, is called a soothing term - externalities. Therefore, GDP reflects not only the crisis of the time, but also narrowminded assumptions of economists. Some critically oriented economists state that the use of GDP as a measure of the "progress", "growth" and "development" - is not only outdated but also perverse. The GDP not only conceals the breakdown of families and communities, and depletion of the natural environment but, in fact, it seems that these breakdowns - which are reflected in such things as car accidents, divorces, and the construction of new prisons appears to be an economic profit. Jeremy Rifkin argues that the mode of GDP as such is that it does not manifest items related to the quality or the quality of life (such as a greater amount of leisure time), health, decent and non-violent education and life in the communities of a safer and environmentally cleaner environment. The definition of quality of life depends on a set of non-material aspects of life such as health, social relationships and quality of the natural environment. There are no better indicators of well-being of a certain society than the public health and safety. Before Obama's health sector reform in the United States, Rifkin noted that the sad fact is that the United States and South Africa are the only two countries in the world that do not provide health care to its citizens. More than 2 million Americans were in a prison back then - a quarter of the total prison population in the world. The American dream is increasingly becoming a sobering wake-up for impoverished American citizens (or it is a shy announcement of a global democracy that is about to come) and the European dream - which nurtured in the lap of beautiful hopes - they both fought for supremacy on the issues of health, leisure, welfare, safety, risks of global warming, the risks of consuming genetically modified organisms, the quality of education, health care, human dignity, healthy interpersonal relationships and life in harmony with nature. If we want a sustainable global society, it is important that programmatic policy-makers at all levels of development incorporate some form of environmental accounting in their decisions. For instance, according to some proposals, the preservation or loss of valuable 
environmental resources should be included in the estimates of economic growth and welfare of men. We are looking for a suitable alternative to GDP: The Index of Sustainable Economic Welfare (ISEW); the Genuine Progress Indicator (GPI); the Fordham Index of Social Health (FISH); the UN's Human Development Index (HDI); the Index of Economic Well-Being (IEWB), are among the most popular indicators. Each of them sought to determine the "real" improvement of human welfare. People are becoming aware that the so-called new knowledge economy, in addition to positive contributions to developing the vocabulary, discursive strategies and the effects of the ideology of free markets, produces and plays an aggressive, technicized and unifying culture. It is, in fact, a hyper culture and a culture of materialism, selfishness and infantilism - or briefly - the culture of death. For the first time in history, the basic unit of economic activity is not the subject, whether it be the individual (such as the entrepreneur or entrepreneurial family) or the whole collective (such as the capitalist class, the corporation or the state), but it is the system units. This leads to the dominant cultural forms in organizations of informationalism of "corporate ethos accumulating" and "the renewed appeal of consumerism" (M. Castells, 2000). We are witnessing the violent realization and promotion of commercial culture in which there is no public space, but there is only market space. In the 1970ies, the idea of neo-liberal theorists is, thanks to their direct impact on the number of politicians and governments, given the opportunity for its practical application, with the increased economic stagflation of the time which Friedman and the way of fighting against it anticipated through the criticism of Keynes' theory. Military dictatorships in South America - Chile, Argentina, Bolivia and Uruguay - directly supported by the United States, led to overthrow democratically elected socialist government in these countries and the introduction of neoliberal-capitalist, economic and political reforms. All of this corresponds to the arrival of Roland Reagan at the head of America and the beginning of the open practice of neoliberal policies $(\mathrm{H}$. Hromadžić, 2008). The scientists no longer believe in a linear economic development based on the principles of neoliberal policies and market fundamentalism. Neo-liberal, universal, mono-cultural concept of development - after all that happened in the name of free markets and the so-called democracy - reminded us of the "black box" of our advanced civilization. From the standpoint of the global ontology of uncertainty, according to the American dream, the world can no longer serve as a model of social progress. The European vision of the future - as utopian and paradoxical as it can be - had a chance to overshadow the American dream. Once so cherished, the American dream is now increasingly causing ridicule, irony and cynicism (J. Rifkin, 2004). Such recognitions when coming from the Western authors have a great weight. When Rifkin says that our lifestyle does not inspire, but is considered to be overcome or, worse, a daunting one, or even causing disgust - then it should be taken seriously and not just as a thought of a lonely scientist. The key issues of global survival assume the possibility of pluralistic education of global human identity and, in this connection, the search for ways of reducing and eliminating violence against humans and violence against nature. Single, monolithic identity is an ideological construction. It is an identity that often functions as a belligerent, murderous identity (A. Maalouf, 1998 G. Haller, 2002). It is necessary to take into account our multiple identities and thus opt for the relative importance of our various connections and relationships in all contexts. Hope for harmony in the contemporary world lies in understanding the diversity of human identity. The socalled developed societies produce too much noise and cause our senses to be numb. Such 
societies are obsessed with conformity and irresponsibility for the fate of others because they are composed of individuals who are proud of their origin, but are governed by the behavior of others. Expressing visible contempt for others and frantically seeking their approval is the evidence of the pathology of a modern man - a consumer of the spectacle of society and an irresponsible seeker who want to purchase satisfactions. Elevated to an absolute standard, the principles of pleasure in all its pathological and degenerate forms (for example: "Enjoy your nation as well as in yourself") weakens our emotional intelligence directed towards others - and is collapsing into mediocrity and hedonism, stupidity and fatalism. The economic science and economic activity in general, are in tension with the ecology and environmental problems. Economics is, at the same time, tense towards other relationships - the politics, culture, art, etc. These relations are complicated because of the negative consequences of neoliberal "globalization of robbers" (M. Castells, 2000). But bear in mind that globalization has not simply fallen from the sky. It is a social phenomenon that, in essence, has social causes and consequences. In order for it to become so widespread and so active, it was necessary to meet a number of symbolic, cultural, political, social and institutional conditions. In fact, in the social, epistemological and institutional sense - it is possible only when, in the name of the global knowledge society, the economy began to speak as a global knowledge economy does. It is possible only when people and corporations, who had an interest in believing in it, have imposed their own interests as well as global interests. It is possible only when those who possess economic, political, institutional and scientific power, get a unique historical opportunity to impose its beliefs on those who believed them, or those who have not adequately confronted them. With the progress of the economic dimension of globalization, economic and environmental problems have become incalculable. The global economy found itself in conflict with the state, society (especially in the light of recent social movements and "civil society"), as well as the public sphere in general. Insisting that it is possible to have the absolute truth about globalization, has always been a threat as it could turn into some kind of a dangerous ideology or dogmatism. Dogmatism, by itself, is not a problem: the problem is what it makes people do. Therefore, it is important not to give up on a critique of an ideology. The ideology of neoliberal globalization of the world, on the basis of epistemological and market fundamentalism has shown a series of negative consequences because it sought to be even in those areas of life and work (such as for example, education) that can be neither understood nor preserved if we use only the econometric parameters ('efficacy', 'effectiveness', etc.) and models of thinking. To prove this, it would be responsible enough to consider only one problem: the global, regional and local water shortages. What is water? Vandana Shiva, an Indian physicist has shown that at every level of ecosystems (such as air, physical geography, vegetation, geolog ...), modern humanity is abusing the earth and its ability to receive water it absorbs and stores. Shiva is associated with the clash of cultures, the war paradigm. Shiva believes that there is a huge misunderstanding between two cultures: the culture where the water is seen as something sacred, and approaches its supplies as a duty to preserve life and culture that looks at water as a commodity, and interprets its possession and trading as the basic corporate law. The global water crisis is the most present, the most serious and invisible dimensions of ecological devastation of the country. Shiva called this devastation of the earth a corporate terrorism. According to the market paradigm the water shortage crisis occurred because the water is not traded. If, according to the proponents of 
the paradigm, the water could be transported and distributed freely on the open market, and if it could be brought to the deprived areas, higher prices would lead to conservation (efficiency, effectiveness, etc). This is the law of the market, market fundamentalists said, and the water for them is no exception. Market assumptions, may be completely blind to the environmental limitations, set by the water cycle, as well as to the economic constraints posed by poverty. Excessive exploitation of water and disturbance of the water cycle create utter scarcity which the market cannot replace by any other consumer goods. Reasoning used by the market paradigm refuses to see one of the most important moments: when the water runs out - there is no alternative. Therefore, the ecological paradigm should confront the market paradigm. However, in order to end the crisis of water - which is listed here only as an example - it is necessary to change global consciousness of the majority of people, and begin to apply an ecological democracy. Globalized economy of knowledge (and skills) moves the definition of water from the level of joint ownership to the level of (privatized) goods, which, according to the laws of free market can and should be exploited and sold. The global water crisis - mentioned here only in short lines - is a paradigm of the global crisis of the knowledge-based economy. It is also a paradigm of the so-called crisis of the global knowledge society (all the main streams of science see a role model in it, not just those in the West) and, finally, it is the paradigm of global, bioethical and ecological crisis, which is now in a radical social and epistemological conflict with the new knowledge economy. In this sense it is worth repeating that the causes of water crisis are business related, but without marketing solutions. We support the bioethical ecological paradigm in the context of recontextualization of sustainable development but also in the context of aspiration towards holistic ontology of knowledge, education and human health. Bioethical ecological paradigm is necessary to apply to other areas of critical analysis of the negative consequences of economic globalization. The reason is very simple: It takes only one step or less from abstract requirements for market deregulation to the dubious corporate law for the privatization of water, air, and the whole country. It is wrong to measure the size of this step through the econometric criteria. Therefore, what is necessary is an alternative interpretation of Reality. It is also necessary to have different ways of thinking and more humane and equitable criteria for measuring quality of life. There is a talk about indicators for measuring the very quality of the indicators of economic (and social) development. The quality - that is the very notion of quality - reduces the quantity and qualifies that way. Quantitatively defined indicators for measuring the quality (used only for measuring quantity indicators) cannot be indicators for measuring the quality - the very concept of quality. That is because people themselves who are affected, let's say, by the devastation of their life or cultural habitat - or live in permanent fear of hunger or fear of (the war against) terror - have plenty to say about the quality of their lives, or the negative consequences of neoliberal globalization. The social and health consequences of the global economy (which claims to be knowledge-based), are best explained by the reality. Keepers of the present order promote a simple thesis that globalization benefits all. This is only superficially true. Who are we? Who proved that globalization benefits all? Globalization benefits the minority so they could exploit the majority because the majority allows them to do so. This means that globalization does not benefit everyone, but only a small number of people. A total of $1 \%$ of demonstrators is in front of the Wall Street. The gap in income inequality in the United States is increasing. The financial wealth of the richest $1 \%$ of U.S. households exceeds $95 \%$ of 
the total wealth of households, reflecting a significant increase in the last 20 years (Stegar, 2003). The group of scientists in the U.S. recently warned that economic globalization could be the biggest threat to prevent the spread of parasitic diseases in sub-Saharan Africa. They pointed out that pharmaceutical companies with headquarters in the United States stopped producing many of the anti-parasitic drugs because developing countries cannot afford to have them. Assets of the three wealthiest world billionaires, is more than the total national product of all the least developed countries and their 600 million inhabitants (Steger, 2003). This is called a knowledge society. "Knowledge society" can only negate the cost to self harm - ironically says Konrad Liessmann, the author of Theory of lack of education - errors of the knowledge society. From the point of knowledge-based economy, quantitatively expressed "life expectancy" for each country of South Africa is: Angola (Men 37, 4 years of age; Women 39, 9 years of age), Zambia (Men 37,1 years of age; Women 37, 5 years of age), Malawi (Men 36, 6 years of age; Women 37, 6 years of age) Mozambique (Men 37, 3 years of age; Women 35, 6 years of age), Namibia (Men 36, 8 years of age; Women 37, 5 years of age), Botswana (Men 36, 8 years of age; Women 37, 5 years of age), Zimbabwe (Men 38, 5 years of age; Women 35, 7 years of age), South Africa (Men 47, 6 years of age; Women 48, 6 years of age), Lesotho (Men 48, 0 years of age; Women 49, 7 years of age.) Swaziland (Men 37, 9 years of age; Women 39, 4 years of age), Madagascar (Men 53, 1 years of age; Women, 57, 7 years of age) Mauritius (Men 67, 3 years of age; Women 75, 3 years of age) Comoros (Men 58, 2 years of age; Women 62, 7 years of age). The common goal of a series of social movements that support global responsibility of a science and corporations towards the people and the earth is to establish a sustainable development of regional and local communities on the principles of planetary awareness, solidarity and global civil democracy. If we look at the intellectual history of mankind, the chronology of ideas, then we can see that ecology has almost never been seen as a key issue for survival of man. Since the beginning of recorded history, until recent times, economic ideas, in addition to various theological, political, and sometimes philosophical ideas, occupy a very important place in human life. In contrast, with some exceptions, the story about ecology is mainly of the recent date. There are, for instance, comprehensive intellectual history books of Europe, where we can find a display of very different traditions of thought, from the Judeo-Christian and Greek and Roman traditions, to post-structuralism and postmodernism, but they almost completely ignore the environmental problems of humanity (see: Marvin Perry, Intellectual History of Modern Europe, Houghton Mifflin, 1993). In addition to this, some authors who deal with the history of economic and political ideas treat ecology as an ideology (the ideology of the environmental protection or environmentalism (See Andrew Heywood, Politics, Originally published by Palgrave Macmillan, 1997, 2002). If ecology is treated merely as a form of ideology among other ideologies, then we are at risk. We forget that we are referring to the quality of the water we drink, the quality of air we breathe, the quality of the food we eat and, more broadly, the overall sense of social and natural conditioned communication that we achieve. Only the recent theories on economic development which have been occurring in the recent years, began to analyze the relationship between economy and ecology, focusing on environmental problems and environmental pollution (see, Michael P. Todaro and Stephen C. Smith, Economic Development, 2006). Complementary studies with a common basis in economic, environmental and development related issues reveal serious shortcomings of conventional knowledge-based economy. The problem is that economists' 
openness towards the environmental problems, is often done blurry and in a sign of the econometric concept of sustainable development. The strategic coalitions are often made for development planning, which correspond only to a privileged group of several powerful people (see, Amy Goodman and David Goodman, 2004.), whereas the responsible consideration of sustainability implies a global change of consciousness and sustainability for people and communities. (For a comparative analysis of the previous definition of sustainable development take a look at: Sharachandra A. Lale, "Sustainable development: A Critical Review," World development 19 (1991): pp. 607-621, and Lance Taylor, "Sustainable development: An Introduction," World development 24 (1996), pp. 215-225.). To sum it up, people who deal with the problem of environmental sustainability as a term used to describe the desired balance between economic growth and environmental preservation. Although there are many definitions, sustainability generally refers to "meeting the needs of present generations without compromising the needs of future generations" (World Commission on Environment and Development, Our Common Future (New York: Oxford University Press, 1987): p. 4.). The implicit fact in these statements is that the future growth and overall quality of life depends on the quality of the environment. The basis of country's natural resources and air quality, water and soil are the common heritage for all generations. However, conventional theories of sustainable development do not pay enough attention to post-colonial and alternative theories of development. They do not pay enough attention to different traditions and environmentally-conscious culture of life. In countries like India the opinion that has been traditionally circling around is that space, air, water and energy are excluded from ownership. In Islamic tradition, the right to water is basically based on Sharia law, which originally quoted "path to water". In the United States, there were those who advocated water as a common good. "The water is moving, wandering, and it is necessary that according to the law of nature it remains everybody's," wrote William Blackstone, "so I can have only temporary and transient, as the enjoyer."With the globalization and privatization of water resources midst, a new effort to completely undermine the rights of people and collective ownership of resources replace corporate control. In that race it is often forgotten that in addition to the state and market, there are alive (and life-threatening) communities of real people with real needs. (V. Shiva, 2002.) Private interest groups and large corporations, in an endless race for profits, even go so far as to systematically ignore the option of joint control over the water. After twenty years of "shocking" (N. Klein) and doctrinal ignorance of the actual social and human consequences of unfettered global capitalism, the president of the World Bank came to the conclusion that for most of the world's population, the word "globalization" includes "fear and uncertainty," and not "opportunity and inclusion "(International Herald Tribune, 02 October 2000, page 13). Even Alan Greenspan and Treasury Secretary Larry Summers agreed that "antipathy towards globalization is so profound" that the "withdrawal from the market-oriented strategy and return to protectionism" are the real opportunities (E. Hobsbawm, 2008). Real people and their primary human needs, their health and educational needs - are ignored under the influence of fundamentalisms which compete with one another and people - regardless of their differences - are seen as a means of achieving some other goals (S. N. Eisenstadt, 1999; K, Kienzler, 2001., Z. Sardar, 2002., S. Sim, 2004). Negative effects of the dominant ideology of market fundamentalism (and its inherent corporate terrorism) cannot be eliminated without prior social-epistemological, multicultural, trans-disciplinary and anti-capitalist critique of 
social, institutional, and (privatization) abuse of the very idea of knowledge. It is also not possible without a radical critique or 'deconstruction' of the corporate structures of universities as the highest institution of knowledge. Universities of knowledge cannot be without serious consequences for the very idea of humanity - reduced to the malls. Future universities of knowledge, "which could happen tomorrow" (Derrida, 2000), should not be organized solely on models of market-oriented factory complex. Universities that are focused on knowledge should not be used exclusively for the promotion of private and fast cost-effective corporate business, not in reality and neither by the definition. Generally, universities in should not be defined solely by criteria of satisfaction (in combination with a higher or lower dose of tabular terror by students or professors). If it is true that we live in a global knowledge society, as stated by the new knowledge economy (something that everyone tends to repeat), the question is, how we get on the edge of a real disaster. Serious programs of reconstruction of a so-called knowledge society cannot be sustained without the reconstruction of the university. This has been pointed out in a variety of programs beyond the reconstruction of our systems of knowledge (Giddens, 1996; Ritzer, 1996; Derrida, 2000; Rorty, 1989; Wallerstein, 2001; Beck; 2007; Pachura, 2011). Corporate Research permeates everything. Knowledge acquisition is now collecting data, and data collection is the processing of changes that occur over time. Such a linguistic metamorphosis opened the door to the new interpretation of being as pure process devoid of any kind of final, unchanging frame of reference (J. Rifkin, 1998). One of the major themes of globalization is education - a dramatic transformation of our institutional systems of knowledge. The crisis of the project of globalization is associated with the deconstruction of our systems of knowledge. This deconstruction cannot be represented in a character or a key. Comparison between the state of education in the developed parts of the world, such as the U.S. or Europe, reveals some very interesting facts. Developing countries have their own problems in all the areas, including the area of education. Very little is known about these problems in developed countries. Nowadays, developed countries are facing a difficulty, where instead of true knowledge and education, they have been dealing with autistic administrative protocol exegesis of performative effects of Bologna, for many years. The university that we could have tomorrow - is a university with the right questions being installed and questioned, a university where "nothing is secure before a question. This is connected with the analysis of what is happening today, "on the world stage and, combining confession, repentance, atonement and asking for forgiveness in one general process" (Derrida, 2000). Global society of knowledge and skills is the ultimate result of the universalization of the universal economic language. Who would ever go against the global knowledge-based society? Who could be against freedom of the global linguistic exchanges that take place (i) in the name of knowledge itself (ii) in the name of freedom itself? Who could be against the free market in which there is a free trade of knowledge - where we can freely exchange words and things, things and words, people and things? Derrida also writes the following: "The event is detected on the basis of one that might not be aligned with the possible, but the impossible. Its power is therefore irreducible to the strength or power of the performative, and if such strength eventually gives her opportunity and efficiency to its performative, it is called the performative force" (Derrida, 2003). This distinction, the distinction between performative speech acts and the constant ones was one of the major events of the last century - and it is, says Derrida, the first one that was an academic event. It 
happened at the university and in a way social sciences are the ones that encouraged and examined its sources. It happened within the social sciences through the social sciences, and has far-reaching consequences (Derrida, 2000). Instead of thinking, the new economy based on knowledge, in order to educate the global knowledge society recommends, suggests, provides excellence, quality and satisfaction, and who would be so narrow-minded to refuse this generous offer. Luhmann's critique of techno-science has shown that the ability to design technical devices are not really all based on a better understanding of nature and the "implementation" of its "laws", but the growing ability of decomposition and recombination of Sciences. Technological advances were achieved without any prior scientific knowledge in many cases. It is not known that a major scientific discovery happened because of favorable intellectual climate that was produced by "Bologna". "Technology is the kind of observation that takes some consideration from the standpoint that it can break down," and based on many empirical analysis of today, the conception that technology is "applied science" can be considered to be defeated. On one hand, technology development cannot be understood as a kind of turning science from its own interests, or on the other hand, as restriction of its autonomy. Can technology be socially and politically acceptable and economically used, is another question to be decided outside of science. Providing a usable technology is the result of science, not its function. It may be that the science is appreciated and financed or even criticized because of such results ... No matter how you define the conditions of action, there can be no question of separation of science and scientists from the company (N. Luhmann, 1991). Similarly, the 'Bologna process' (with its obscene combination of excessive use of "satisfaction" and tables of terror), cuts the very essence of the importance of establishing a global knowledge society on the basis of new economy based on knowledge. The central contradiction of the Bologna educational policy concept of knowledge is in (the key corporate) assumption that there is not a qualitative difference between technological process of goods production and services, and educational and pedagogical process of education and the formation of personality and neither there should be. Bologna might result in the widespread wealth and prosperity one day, if they managed to bring corporate governance to prevail (be dominant) over the public good and private interests. In order to make the motive of profit lead to the best possible education, three requirements must be met. Students must know what they really need to be able in order to evaluate possible alternatives and make reliable decisions. Finally, their wishes must suit the needs of society, as one of the important roles of education is to prepare people to effectively contribute to the common good (Derek Bok, 2003). Stiglitz has explained in detail how "modern economics has shown that social welfare is not maximized if corporations are solely focused on maximizing their own profits" (Stiglitz, 2007). N. Klein has deconstructed a 'scientific' role of Milton Friedman, wrote 'The Shock Doctrine', and elaborated in detail the causes and consequences of the rise of disaster capitalism. André Gunder Frank accused Milton Friedman of "economic genocide". Klein defined catastrophe capitalism as a planned raiding of the public sphere after catastrophe, combined with the notion of tragedy as exciting market opportunities (N. Klein, 2008). Everyone who is preoccupied with the future, not only the future of global capitalism but also a future of sustainable humanity, is not always sure where to direct analytical view of the research: "The extreme right wing talks about the problems of globalization and mondialisation, and then focuses on the problem of migrants, who themselves are the victims of globalization, rather than its cause. Dissatisfaction should 
be re-directed to the real causes of the problem: large companies and mere search for profits, a behavior that destroys human communities everywhere in the world creates instability (Colin Crouch, 2003). It has been pointed at the fact that a man is in a situation where the global human survival is threatened. Man is exposed to major risks due to changes in the environment that he himself produced by creating nuclear weapons and ballistic missiles. "Our power to kill gained a universal character which led to a radically new situation where, if we want to survive, we are required to adopt radically different attitudes towards the provision and imposition of advice and also towards the interpersonal and international relations" - says Senator J. William Fulbright in book, The Arrogance of Power. According to Brzezinski, the power of America is based on four elements: (1) global military power, (2) global economic impact, (3) global cultural and ideological influence, and (4) global political influence. Although America, according to the insights of the nineties, does not have a worthy competitor, the position of global leadership is highly unstable because it is deeply caught in the "paradox of global power." It has a military impact and will have a major military impact for a long time. Economically, its impact is questionable because there are new world regions with great economic potential. Of all the global powers, the most contentious one is cultural and ideological. Brzezinski pointed to twenty deficiencies that question America's leadership role in the world. These short comings are debt, trade deficits, low savings rates and investment rate, industry uncompetitiveness, low rate of productivity growth, inadequate healthcare, poor high school education, poor social infrastructure and the decline of cities, greedy wealthy upper strata, parasitic obsession with litigation, deepening racial problems and poverty, crime on the increase, the use of drugs, instilling hopelessness, the spread of sexual freedom, the spread of moral depravity through the mass media, the weakening of civic consciousness, the emergence of divided multiculturalism, the collapse of the political system and increased sense of spiritual emptiness (Brzezinski, Zbigniew 1997; 2004). Another defect to add to the list, probably the greatest one (for which out of the irreversibility of social events in reality there is no adequate substitute), which has been detected only now, is a democracy deficit. For the first time in the history, American citizens are confronted with a "deficit of democracy", in a country that for many people around the world represents a model of free, democratic, liberal society. In fact, it happened only recently that America began to deal with its own myths, in a far-reaching significance. It is presumed that the libertarian protests of Americans against injustice, hypocrisy, greed, banks and many other things will take a more important place now than before. But there is also a danger that America could postpone the great historic opportunity of responsibly dealing with their own myths - for some unspecified time - in order to focus on internal democratization of their society. A critical expression of "market fundamentalism" seems to have come too late. This phrase 'too late', wanted to warn that society cannot be reduced to the market or a global "labeled" (H. Becker) religion - any religion. The only fundamentalism, which the global public is constantly "informed" of, through the media, is another form of fundamentalism - Islamic fundamentalism. The problem, which also attracts the attention of the global democratic publicity is in the domain of uncontrolled use of science and technology in economic conditions dictated by the logic of market fundamentalism. Private corporations, which have enormous power, apart from the democratic public control, make decisions that affect us all, even in terms of our chances of survival. Engaged intellectuals point to the social responsibility of corporations and they 
propose a kind of revival of active citizenship, a broad public debate about the consequences of irresponsible corporate governance (see, Letica, Slaven, 2009) where they question the foundations of anonymous logic of market relations. Markets are generally imposed as a neutral fact, but it ia quite contrary. Slavoj Zizek reminds us that, none other than George Soros, the embodiment of financial speculation, came to a conclusion that unlimited role of the market represents a greater threat of communist totalitarianism, and therefore should be limited by certain socio-political measures. However, is this view is sufficient regarding the scale of financial, political and moral crisis that we are in? The problem is that none of those who so convincingly describe the deadly vortex that we have been drawn into by the so-called process of globalization, does not have a anything defined on how we can get rid of capitalism (S. Zizek, 2004). Instead, the relevant parts of the former totalitarian regimes of knowledge are still at the scene of misreading wrongly formulated dilemmas of what was worse: Nazism or communism? New theoretical directions which propose various measures to overcome the "undefeated traumatic past," are in the process of developing in the sign of differently motivated cultures of memories (Helmut Dubiel \& Gabriel Motzkin, 2004). Postmodern theorists have gained considerable fame on the thesis that the search for truth is a thing of the past, and that in today's "post capitalist world" (Drucker, 1993) we are doomed to endless recycling of the large number of small, mutually competent stories which we will never see as as a true again. The reason why is that we are, apparently, no longer able to find some solid support out of the language which we could consider to represent the true reality itself. The new knowledge economy responded to the challenges of postmodern social theory, in an original way. It has skillfully privatized only the name of knowledge and combined the concept of knowledge with the new economy - and made a brand of all brands. Knowledge as such has provided itself, its own symbolic and business needs - with the very idea of knowledge. The difference between a postmodern philosophy of free symbolic exchange and the new global economy based on knowledge, which is in the essence of a global knowledge society, that we admire, could be explained only by a radical anti-capitalist theory. This theory, if it was possible, should be able to offer a rational alternative to global capitalism. And such an alternative does has not been created yet. It does not exist because capitalism - in the name of creating the global knowledge society - already declared itself to be a "post capitalist society" and therefore every reason (request) to go beyond capitalism has been meaningless and a surplus in advance. Nevertheless, global capitalism (regarding its consequences), is rather a part of the problem of globalization and not the opposite - its solution. However, the new knowledge economy, in its privileged sense, can be understood as a misunderstanding and misused phrase, which tried to build its power and prestige solely on the absence of epistemological and ontological understanding of the importance of knowledge, whose comprehensiveness is (still) in the mainstream economics in the West. So, what does it mean today to repeat or uncritically assert that we live in a knowledge society? Or, from the reverse perspective, is it possible, and if so, how can we start doubting the idea of a knowledge society without harming ourselves at the same time? At the very level of symbolic appointment, while choosing an appropriate name for the era in which we live, we encounter the paradoxes. If we say that we live in a knowledge society (because knowledge is officially the most important resource), we automatically switch off the field of ignorance. Firstly, we now know that science rarely solves the problem neatly and in an organized way - there are always some elements that are not and cannot be resolved, as in the case of 
radioactive waste generated from nuclear power. These awkward, "unresolved" elements of the problem are usually ignored until suddenly they start to pose a risk in all respects. The problem is that knowledge and ignorance have always been deeply and inherently connected. The new knowledge economy seems to forget or ignore that link, their deeper connection. One of the definitions of scientific knowledge is that science is the art of that what can be solved. Limiting science to the "solveable" has far reaching consequences for our understanding of knowledge and the world. Specifically, that means to completely remove ignorance from the view. Conceptually, it does not seem to be there for us. According to theorists of postcolonial studies of science, ignorance cannot be solved by conventional research. Recognizing ignorance is highly important for a very practical problem of science: priorities and decisions. Because whenever a proposed project is appointed a low priority, its implementation will never happen. Therefore, we lose the chance of gaining new knowledge, and in that sense we remain in ignorance. It is possible to specify a number of examples. If our society is relatively little interested in - sayOccupational or alternative sources of energy, compared to the technologically and commercially developed medicine and nuclear power, we will stay in the dark about these alternatives. Or, if they who finance - for instance - Development Research are totally uninterested in fundamental research in the field of social and multicultural epistemology and, instead, strongly privilege only commercial strategy development, then we remain in ignorance regarding the contribution from possibly critical areas that could be significant for long-term problem solving. What we "know" depends, therefore, on the decisions taken in accordance with those priorities. Therefore, a critical study of science assume that it is necessary to speak of a "deficit of Science" and "accountability deficit" or epistemological lack of knowledge or ignorance of the ontological, epistemological, political, social terms. Transdisciplinary analysis of the tacit assumptions on which today's dominant currents of social science in the West have developed - can be implemented as a critique of the privileged discourse. Considering the negative consequences of globalization it can be a very useful heuristic programmatic work on the critical 'deconstruction' of the ruling "meta-narrative" about the new global knowledge economy and knowledge society. Since Plato's time until Descartes, philosophers have understood the ignorance about ignorance as a separate category. Socrates' goal was to be aware of his own ignorance. Ignorance was an important concept in Islamic, Indian and Chinese science and philosophy. Renaissance authors claimed double ignorance as the worst intellectual failure. The breakthrough came with Galileo and Descartes, who believed that human knowledge is unlimited in the range and perfectibility. Ignorance is, since that time, which was officially the beginning of modern science in the West, taken as a void to be filled as soon as possible. Progressive journey of modern science was really fascinating on many fronts. From the period of collapse of the welfare state the world has not become any more stable or more just, not even more liberal, considering that the conversion of domestic norm of social life, reduced civil liberties (Kagarlitsky, 1999). In Latin America and the United States relationship between formal and informal economy is more or less obvious. People who work in the informal sector ("gray economy") are unemployed and marginalized. In the former Soviet Union, this relationship fell apart, so that the same people ended up working in both sectors (Kagarlitsky, 1999). U. S. and Nicaraguan authors, Roger Burbach and Orlando Núnez, see the only alternative to neo-liberalism in spontaneously occurring movements that require the satisfaction of basic 
needs. New, more just society "will have to appear as a mixture of different national, ethnic, and cultural movements in the world" (R. Burbach, O. Nanez, and B. Kagarlitsky, 1997).

Globalization can be understood as a socio-economic process of the complex dynamics of the structural contradictions and particularly strong and weak points, but for some countries it is understood as an invasion force, which at some point takes clear strategic contours. Scientific and technological changes undoubtedly play a central role in stimulating or blocking the process of global democratization. Internal epistemology of scientific knowledge is not eligible to explain the historians and philosophers how science works and what is even worse, they can easily be dangerous to human life, the environment and a maximum of democratic social relations. Harding believes that it is a suitable moment to grab and use the resources by post-colonial and feminist standpoint grab and that we can try and influence the outcome of this new reevaluation. Slave trade and industry based on slave labour were the crucial labour force of British and French industrialization (C. L. R. James, The Black Jacobins: Toussaint L'Ouverture and the San Domingo Revolution, New York, Vintage 1963; Eric Williams, Capitalism and Slavery, Chapel Hill: University of North Carolina Press, 1994). Different interpretations of globalization will lie in the thesis that the world is becoming more informed and standardized through the technological, commercial and cultural synchronization which seems to be dictated by the West. As a result, globalization is quite frequently perceived as essentially Western "project" - as westernization or "westernization of non-western" part of the plan. However, not even this interpretation can pass by without a strong challenge. Not only is there disagreement over the meaning of global connection to the modern world, but this disagreement is threatening to humans, as rational beings, to become completely unable to actively perceive the foundations of interconnection of the world in which we live. Therefore, it is not surprising that philosophers and scientists have explained in different ways that within the roots of the globalization crisis is a crisis of modernity project - that is the very concept of a crisis of Western rationality (Bidet, Jacques, 1999). Neoliberal capitalism, with the help of the idea of the knowledge society, adopts globalization and at the same time, attempts to suppress any opposition or highlight any alternative to capitalism. Its identification with the natural and normal human condition is the basis for a far-reaching goal: "to turn the entire planet into a giant capitalist enterprise controlled by Wall Street and other world capitalism centers because of only one thing - and that is profit" (B. Berberoglu, 2003; 2010). Criticism (in the knowledge society) becomes an empty symbolic gesture. Instead of having something changed, it only reinforces further the order whose defects it reveals. Such an opinion, which stands up against the system, is drawn into the same logic that lies in the basis of its reproduction. Nevertheless, many structural problems of neoliberal capitalism were uncovered. After protests in Seattle in 1999, the radical left-wing movements have returned in the form of "alter-globalism". New emancipated movements showed up and managed to draw attention to the dangerous mistakes of the system. However, capitalism has largely failed to discredit the idea of socialism. Many actually believe that socialism, rather than market fundamentalism, is the greatest evil in history. Even today, when someone points out the obvious flaws and dire consequences of action of so-called free market, to the majority it sounds as an attack on private property, free enterprise, or basic human rights. It is quite obvious that an effective enterprise cannot automatically result in the efficiency of the whole system. a living system - that is what society is - is not composed only of people 
who are called entrepreneurs. Global capitalism has reached such a level in which maximized economic efficiency (taking into account the technological, environmental, social and cultural issues that arise) leads to undermining the very foundations of society which is in need of balance, in order to survive and evolve. This is not about the bipolar conflict between the concept of economic efficiency and social justice concept, but about the structural contradictions of the capitalist system. Such a system, without epistemological reconstruction of its own cognitive matrix as the ontology of global knowledge society, is unable to reconcile economic and social aspects of their development and reproduction. To sum it up, in reality the company cannot, reduce it the market without its remnant so that people can survive the reduction. Therefore, the authors that can prove that the man is last, remained, unprocessed remnant or it has already become a surplus ("waste") in the global machine of the capitalist self-reproduced capital. The consequences of the global dominance of market fundamentalism are far more complicated than they are presented by media and its protectors of privileged flows of Sciences. The key social problems of people, communities and entire regions need to be simplified as much as possible, but no more than that. Intellectuals of the late twentieth century socialism first began to appear not as an alternative to capitalism, or as a new form of social organization, not even as a political movement, but rather as a set of values. The question that came forward was: 'what kind of values will control the age that is about to come?' It is not necessary to wait for long to get answers to this question, whichever side it was that the answer came from it was hardly a theoretical one. In 1999, after decades of neoliberal hegemony on the world markets and the collapse of economies of East Asia and Russia, a possible global crisis was speculated unless greater control of financial markets could be achieved. Pessimism was a logical consequence of a triumphal illusion of the 90-ies. The current, global financial crisis is intertwined with many other crises. Its roots are deeper than what the narrow-minded economic analysts (apart from a few exceptions) assumed a few years ago. Firstly, it was revealed that there are many myths related to the so-called free market and the so-called deregulation. Apparently, such a thing never existed. Secondly, it is not true that there is no regulation that controls the global "free market". The only way it can work is because of this regulation which allows global financial flows, provides a legal guarantee of loans, determines exchange rates, etc. The national "deregulation" or the end of protectionism, which has enabled globalization, and is now largely reduced to the control of nation states over the domestic economy has a background in various forms of international regulation (Altvater and Mahnkopf, "the World Market Unbound," in: Scot A. (ed.) The Limits of Globalization: Cases and Arguments, Routledge. London, 1997. Humanity today has faced a triple crisis: poverty, social disintegration and environmental degradation. The last century can be called the century of the apparent development. The negative consequences of globalization are associated with a deficit of global social responsibility. It is necessary to analyze the role of international financial institutions and commercial banks, which - guided by their own greed - have contributed and placed the largest number of countries in Latin America and sub-Saharan Africa today in such a desperate state of underdevelopment and poverty. Privatization, liberalization and constant competency struggle in the market are the most important values of neo-liberal ideology incorporated into the foundations of a new model of social development, of a so called Washington Consensus. The new model is to be reduced to a model of controlling the society, which is perceived as a supplement to the market. The 
theory that the victory of private property itself will rapidly create a class of independent entrepreneurs, without an adequate institutional and legal framework, has been proved to be wrong in practice. In fact, privatization did not only fail to help in the process of modernization of economies of Eastern Europe, but it was also closely associated with a reduction in exports. Industrial growth was recorded in the Czech Republic in the period of 1989 - 1997 where privatization is only got simulated (privatized companies have bought state-owned investment banks). Y. Buzdugan, an economist who analyzed the results of liberal reforms said that it appeared in those countries that did not follow instructions of IMF - In China, where the communist regime survived and Belarus, where, after several years of crisis, President Alexander Lukashenko came to power, even though he wasn't favoured in the West. Productivity growth crisis was much greater in sectors in which privatization was only partial. (Y. Buzdugan, "Sotsial-demokratichniy vibir"). Kagarlitsky believes that in 1989 most citizens of communist countries were completely indifferent towards the fate of people in Africa who were dying of starvation or people in Asia who lived in poor conditions. Poverty and instability that have spread like an epidemic across Eastern Europe, is a kind of historical retribution for irresponsible fantasies of consumerism and racist contempt for the rest of the world (Kagarlitsky, 1999). Structural exclusion of Africa from the dominant flow of economic globalization is a loss for the international economic policy and for what the West calls the "new economy of knowledge and skills". Professor Michael P. Todaro, who has lived and taught in Africa for 5 years, tried to incorporate his experiences in the theoretical concepts of Western development. Although he drew attention to the tragic problem of structural underdevelopment and poverty in subSaharan Africa, he still could not completely avoid westernized interpretative strategy while analyzing the reasons for the tragic situation in that region of the world: "The "lost decade of the 1990's", only brought new losses after the previous "lost decade of the 1980's", which mostly hit Latin American countries, and many other developing countries. By 2005, there were no clear signs of reversal. Africa, has recently recorded two successes - Botswana and Mauritius, but they are only rare exceptions... Serious cuts on spending in health and education in the 1980's which were partly caused by credit conditions that were set by the IMF and World Bank - have resulted in a sharp drop in school enrollment and the disturbing rise in malnutrition and maternal and child mortality. For example, by 2003 there were over 200 million severely undernourished people in Africa. The mortality rate of children under 5 years of age in 2002 was the highest in the world, at the level of 174 per thousand inhabitants. Todaro says that "sub-Saharan Africa is facing a difficult period ahead". The positive trend is that many African countries have begun to come out of the process of economic decline in the early years of this century, and some are beginning to show an accelerated economic growth. However, famine spread across South Africa and countries like Ethiopia. If we want global development to be successful, Africa will be the hardest temptation. If it fails, not only will a total of 700 million Africans who live south of the Sahara be sacrificed, but directly or indirectly, the rich countries of the industrialized world will have to bear the huge moral responsibility for this failure, as it will bear the consequences for human health and the environment" (Michael. P Todaro and Stephen C. Smith, 2006). If the 21st century wants to give a promise to less developed countries (LDCs) that have not been able to participate in the fruits of (the so called) global progress, then effective management - in terms of money, finance, environmental issues and the flow of 
resources, labor and technology - will require reform of the international system. Among the most frequently mentioned changes were: (1) The creation of new sources of financing for the LDCs: tax on international financial transactions, such as the so-called Tobin tax to reduce speculative inflows and outflows of foreign capital and (2) reform of the two main existing institutions of global economic growth and stability, the IMF and World Bank. Todaro says, to hear how the poor in their own words explain what it means to be poor is much more distinct than listening to a description of poverty. Therefore, he repeats the voices of the poor:

- When the woman is poor, her voice is not heard, she feels inferior. There is no food but famine in her house, no clothes and no progress in her family (the poor woman from Uganda).

- For a poor man everything is terrible - illness, humiliation, shame. We are disabled; we fear everything and depend on everyone: Nobody wants us, we are like garbage that everyone wants to get rid of (a blind woman from Tiraspol in Moldova).

- Life in this area is so difficult that all the youth and whoever can, must run to other cities or go to the army and on the front to satisfy their hunger which seems to escalates here more (the participants in a trial in rural Ethiopia).

- When food was abundant, relatives would offer to help. In these days of famine, not even relatives are willing to help and give you something to eat (The young man from Nichimishi, Zambia).

- We are forced to stand for hours in line for a little water (the participants in a discussion in the village of Mbwadzula (Mangochi) in Malawi.)

- Poverty means... low wages and unemployment. It also means lack of medicine, food and clothing (the participants in a debate in Brazil).

- $\quad$ Do not ask me what poverty is because you found me in front of my house. Just look at my house and count the holes in it. Look at the appliances and what I'm wearing. Take a good look and take note. What you see here is poverty (the poor in Kenya).

The concept of the idea of humanity is faced with the loss of elemental humanity in us, especially when we say that we live in a global knowledge society. We could therefore speak of a (possibly infinite) difference between what Todaro calls an economy of survival in sub-Saharan Africa and the "new economy of knowledge" in the West. We cannot understand this infinite difference on the basis of a studied 'double hermeneutics'. The words spoken about the recent solidarity in Africa are as cynical as they may sound. In order to understand the pain and humiliation of the poor, we need the emotional rebirth of humanity and epistemological mutation of consciousness - the opening towards the global responsibilities. It is necessary to expand research and methodological procedures of the development economics. What is needed is a holistic social ontology, which, instead of a linear progress and development of science and knowledge, perceived defects of progressive development paradigms, and therefore turns towards ethics, ecology and sustainable development. Criticism of the knowledge society implies a critique of monocultural paradigm of growth and development. The idea of a global knowledge society cannot be based on the privileging of Western theory and practice of progress, growth and development. There is not only one science, just as there is not only one type of rationality. The critical theory of scientific knowledge in action is open towards a concept of sustainable 
development and moves from the starting point of the existence of different regional and local communities, of their interdependence and interconnectedness. Also, it is necessary to take into account the common destiny of all creatures on earth. It often came to the light that while solving global problems it always had to do with the deeper, global interconnection of social and natural world. Science - if it wants to be sustainable - is not possible without the ethics of responsibility towards the other. For the survival of the idea of humanity, which is the basis of international law - it is necessary to obtain a trans-disciplinary understanding on ethics of responsibility towards others, if we want to make sense of living on earth. Influenced by the new knowledge economy, the ideology of market fundamentalism and corporate banking terrorism, the very idea of humanity is in grave danger. The market fundamentalism threatens the diversity of natural and human world, as it is everywhere. From London, to Moyotte, the extreme southeast of the Comoros island - on the metaphysical level, it has turned time into money, space in the market, and opinion in the calculation. On a symbolic level, variously motivated abuses of collective identity also represent a danger. Homogenous, militant actions of religion abuse (Religion fundamentalism) are especially dangerous. So, how come that one tendentious idea of "clash of civilizations," of the 1990's in the 20th century, which is full of errors, could become popular? The answer to this question is connected with a number of other issues. Another question is how human beings understand (construct) or use their own individual and collective identity? Based on what criteria how are human beings classified, ranked and sorted, and how much do they differ, identify, and share? Are human beings characterized by what they do or what they fail to do? And most importantly: how do human beings relate to the pain and suffering of others - and to the violence against others whom they do not know? What is the role of human rights in the regulation of the cruelty that human beings inflict to one another and lastly, can human rights be overestimated in relation to our responsibilities and duties? What are our responsibilities towards other human beings and why do we say that there are sometimes situations where it is justified to commit violence against other people? In the mainstream of commercially focused economics these questions are hardly ever discussed. Critically orientated researchers on different sides were searching for answers to these questions and other related questions. Over the last 10 years, globalization researchers responded to the removal of the conditions of human life itself. Others affect us in a way that we did not choose. Three days after 11th September in 2001 Judith Butler was among the first who argued that the U.S. has internationally tacit and supported legal responsibility for the people of Iraq. The common condition of existence which we share with others is pain - the pain that identifies us as human beings. However, a philosophical problem with which we work is systematically undermined by the conditions under which "those other people" are represented in the dominant Western media, because they are displayed on the infinite distance and through all the manners of moral veils. It takes a certain amount of humility, courage, and above all a global responsibility to function in such a shaken international framework. After 11th September, many have changed course in the American entertainment industry, as the "margin of tolerance" become lower. Now, all the intellectuals, who do not want to be idiots when it comes to the scenario of conflict between "the West" and "Islam" must direct their top priority towards a strategy that reduces the mutual enemy forces (Thomas Hylland Eriksen, 2002). Various artists and authors, who belong to different cognitive, epistemological and 
research orientation, have suggested that any interpretation which claims that religion is a source of conflict not only insufficient, but it is wrong.

There is not such a thing as only one "West", just as there is no a fully monolithic conception of religion. Also, there is not only one America. George W. Bush's America is not the same as America that is coming - America of the ordinary citizens that are being born. The concept of democracy as well as democracy itself, we cannot have as a property. Democracy is always arriving, that is what J. Derrida explains with an utter patience in his Voyous (Deux Essais sur la raison), which deconstructs the dilemma of whether there is only one Rogue state or has more. The point is that globalization is changing the moral world, so that the responsibility extends much further than before. No more space on the planet that is outside our area of responsibility. A Norwegian philosopher argues that politics often creates a greater evil in an attempt to defeat the lesser ones, and "the greatest problem of mankind is not so much excess aggression, but lack of thinking. This deficiency leads humankind to accept and even participate in the most amazing attacks on their neighbors" (Lars Svensen, Ondskapens philosophers, 2001.).

Events that occurred and their geopolitical and geo-economic effects have created a very popular relationship between the U.S. and Europe. People start to look at social problems in Africa, Latin America, and Eastern Europe in a different way. The civil international public follows the democratic protests in front of the Wall Street, as well as protests in London, Paris, Madrid, and Rome in a different way. Economic, political, social, institutional and legal dimensions of globalization are supplemented with others. After World War II, Europeans, as it is formulated by J. Butler, realized that an international set of institutions, identifications, covenants, and engagements, is actually what keeps the prospect of peace in their lives. In discussions of globalization, before the actual research findings and interpretations, the background presumption of conversation should be a philosophy of peace and accountability. In Europe there is a commitment to multilateralism, it is because nationalism is seen as a huge problem, one that feeds and encourages violence. From the standpoint of social expectations, human rights should not remain completely abstract, and should pay attention to how they are implemented. The process of finding meaning that they have, just as in what idioms they can be found in different cultures, is an act of universalization. Here, the question of antagonistic interpretive practice in the interpretation of the universal in universal human rights arises. Unless we want one-dimensionally understood Western culture to impose a universal right on everyone, then we must understand that the "universal" is constantly creating and always articulates and rearticulates, under conditions of cultural translation. Various governmental and nongovernmental organizations are involved in the complex issues of social understanding of human rights. But no one has an absolute monopoly on the interpretation of the meaning of human rights and human duties. However, a major responsibility lies on the developed countries. They have the power to dictate the conditions under which it is possible to allocate money for the development of those countries that do not have that power. We are to be careful regarding cautions on the responsibility of the international financial institutions in the context of the new global economy. Imposing programs of liberalization and deregulation of markets and institutions are coordinated to contribute a certain region sink deeper into despair, poverty, and even ethnic conflict. Africa is a dramatic example of 
structural exclusion from the global information economy. Because of the lack of insight and sense of responsibility and because of the faults of the international financial institutions Africa has been brought to an entirely specific situation. Only a few of the states in the north, which are the demographically closer to Europe, are in a somewhat better position, while the inhabitants of the eastern, central and southern parts of Africa are faced with the existential problem of survival. This is a situation of structural irrelevance, which is worse than the humiliation and worse than depending on others to help. After the oil shock in1979 and an increase in interest rates caused their bankruptcy, most of the African economies came under the direct supervision of policies of international financial institutions. These institutions have imposed liberalization measures allegedly aimed at creating trade and investment. Fragile African economies have failed to resist the shock. While liberalization policies could not attract investments and improve competitiveness, they destroyed large sectors of natural agricultural production. As a result, African countries are left without defense against a bad harvest. When the drought affected Central and East Africa, famine spread (Sahel, Ethiopia, Sudan), which was worsened by the civil war and banditry, which originated in governor's military confrontation between great powers (Ethiopia, Somalia, Angola, Mozambique). Since the state administration, as intermediaries between their own countries and the miserable resources transferred from abroad, were the main source of income, control over the state administration has become a matter of survival. Since the tribal and ethnic networks were the safest bet for winning people's support, the struggle for control of the state administration (often equated with control over the army) was organized around ethnic cleavages. In this way, the centuries-old hatred (which is the Western stereotype to explain the causes of conflict) revived along with biases: genocidal tendencies and widespread banditry in the root of the political economy of African exclusion from the new global economy. However, what we can say about the experience of transferring Africa in the new global economy is that the structural irrelevance (from the point of view of the system), is a condition that is far more dangerous than addiction.

Such a structural irrelevance was found throughout the 1980's when Africa, following example of debt crisis, forced policy adjustments through the application of abstract formulas in unique historical circumstances: under the dominance of free market conditions, international and domestic, the biggest part of Africa ceased to exist as an economic entity capable of life in the information / global economy. According to Castells, the most likely prospects for future development in Africa arose from the potential role that could be played only by the democratic South Africa of the black majority, with strong economic and technological ties with the global economy. Stability and prosperity of South Africa, and its willingness and ability to lead their neighbors as primus inter pares, offers the best chance to avoid a human holocaust that threatens Africa, as well as the chance to feel humanity in all of us through Africa (Castells, 2000). Perhaps the practice of cultural translation, that Butler speaks of, in a number of cases may represent an alternative to the brutal imposition of the dominant culture on those cultures that are (in relation to the dominant) defined as "others." Moral, religious and cultural differences in matters such as abortion or embryo research are very common in different regions of the world. The 20th century - with a few interrupted intrusions - was marked by scientology religion of Western civilization in the limitless possibilities of analytical science, which has made some fascinating results. This belief is still strongly present (which is best evidenced by 
recursively circulation slogan that we live in a society of knowledge) that the occurrence of critical paradigms, such as global risk society (U. Beck) rarely manages to reach out to the mainstream science. Still, over the recent decades, belief that science alone - without the ethics and accountability - cannot find viable solutions to the crucial issue of the world was challenged. Descartes' analytic epistemology to problems in science broke down into sets of simple, but difficult to solve problems. The researchers specialize on them until they narrow their specialization so that "they know everything about nothing". This logic leads to the destruction of the whole system and the destruction of habitat of living beings who maintain a diversified universe of life itself.

Fundamentally critical studies of scientific knowledge which, in various trans-cultural programs developed in recent decades, have much to say about the crisis of the dominant Western paradigm of knowledge. It is about a range of different studies that are based on the holistic paradigm of knowledge, and that the actual analysis of the negative consequences of globalization are trying to connect with the broader ontological, epistemological, social, hermeneutic, feminist, Marxist, postcolonial, and other emancipated research, science and technology. Almost all of these research studies are very heterogeneous and textual practices tend to get legitimized on the ethics of responsibility, or in other words, on the normative invocation of a global society based on accountability attempting to gradually compete with Western knowledge economy and commercial science in general. In her book, 'Is Science Multicultural?' (Post-colonialisms, feminisms and Epistemologies) Sandra Harding has tried to point out the shortcomings of most existing (and still dominant epistemologies and philosophies of science which the ruling economic science in the West, or so-called knowledge-based economy has also adopted for herself). "The world today when considering issues of science and technology, requires courageous research of unexplored territory, and more communication between people who are rarely found at the same institutional locations (Sandra Harding, 2005).

Postcolonial studies do not only use European and world history as evidence, but rather a widespread post-colonial, multicultural, global history. Along with the accumulation of negative consequences of globalization, comparative postcolonial studies the development of underdeveloped regions and continents became more significant; postcolonial histories of individual states, post-colonial history of neglected or missing communities; postcolonial studies of traditional agricultural preindustrial cultures, postcolonial geopolitical and geoeconomic history of countries that have recently fought for independence etc. Postcolonial studies of development which Harding speaks of, get more importance in the light of recent research for sustainable development in the West. The conceptual framework of postcolonial studies of science and technology was organized from the perspective of other, nonEuropean cultures and the great mass of economically and politically world's most endangered population in their struggle to survive. The importance of these post-colonial studies is that they draw attention to how great the tragedy would be if the human race came to the point where there is only one universally valid scientific and technological tradition. Modern epistemological dream of a perfectly coherent interpretation of all natural laws, the interpretation that perfectly matches the order of nature, begins to take on the form of a nightmare, just as it was realized by post-Kuhn, post-positivist and postcolonial studies of science and technology. The so-called knowledge-based economy - and the uncritical use 
of the phrase-based society - is a symptom of a deeper crisis of the dominant streams of science in the West. However, scientists in the West have come to a conclusion that most of the access to knowledge-based economy is characterized by positivist and non-conflicted vision of knowledge and technology that leads to avoiding the social, cultural and ethical contradictions inherent in the knowledge-based economy. A key methodological limitation of access through the knowledge-based economy is that it forgets that the novelty of the current historical conjuncture does not consist in the simple application of knowledge-based economy, but on the contrary, it consists of the fact that the knowledge-based economy is subordinated and bounded by the institutional forms that define accumulation capital (Didier Lebert and Carlo Vercellone, 2002). It could be shown that the critical deconstruction of the language on which the so-called knowledge-based economy is based and it is the key to recognizing the epistemological and social causes of the crisis of cognitive capitalism (Vercellone, 2002) and the project of neoliberal globalization for postcolonial scholars and scientists in the West. It was similarly formulated by another author: because capitalism is primarily a way of exploitation and social domination, and because the concentrated financial capital dominates the most today, it also creates obstacles on the "cognitive" level (François Chesnais, 2002). For example, in March of 1990, Namibia won independence. However, hardly any viewers in Europe or the U.S. could remember the news. The question is whether the Western media (based on global knowledge about globalization) does adequately tell the news. Perhaps, the Western media of the 90 's were preoccupied with the collapse of communism and the celebration of liberal democracy. After the terrorist attacks on New York and Washington and the American decision to militarily invade Afghanistan and Iraq, the neo-liberal theory has reduced their predictions about the epochal transformation of the world. America is back in the geopolitics of international relations, but the return did not lead to interruption of transnational economic and political ties between countries, but it created new opportunities for cooperation and conflict. The new blow to the credibility of neo-liberal perspective of international relations has once again come from America when the first global economic crisis of 21st the century broke out. It is revealing that Washington has not resolved the consequences of crisis in accordance with the principles of free trade (as they explained it to the dominant neo-liberal globalization theory), but instead used the power of government intervention to save the stumbling banks and companies.

There are anthropologists who believe that globalization is just another name for Western aggressive, colonialist policy that has lasted for about 500 years. They argue that the aggressive colonialism of the West missionaries and conquerors completely destroyed and impoverished many regions of the world. Many native people were systematically murdered in their own country. Thanks to advances in technology weapons and other achievements, the rifle barrel has taken place in the world history of progress: "Hunting, fighting and skirmishes with the Indians in the hinterland, stimulated numerous American improvements of rifles" (Daniel J. Boorstin, 1958). In the beginning, this device was quite cumbersome and difficult. It had a long tube. The length increased the precision, but unlike guns it required the use of both hands and one shoulder. Increased length of the pipe lowered force of the recoil on the shoulder of one who is using it, and added length to the inner path that was used for smoother acceleration of grain. With proper use at the field, 
which included adequate calmness, squint on one eye, not blinking or breathing (without trembling hands) rapidly increased precision. All this has enabled the efficient and effective bargaining of any pre-set goals. The gun - in addition to everything that Boorstin said - was used for "civilizing" the wild Indian tribes. Speaking in a modern, back then still an unknown language, it was possible to assume that the persecution (with the aim of closing Indians in the reserve) happened the way it did. Such events did not have an apparent connection with that what came quite a few years later and was called Total Quality Management (TQM) or "Management by Objectives" (Drucker) in economic theory of quality management. Industrial production of individual shooting weapons and weapons of mass destruction during the process of industrial revolution, as well as postindustrial era, has undergone a remarkable progress. Thus, the gun was carefully refined over the time. With the increase of mass industrial production, the training opportunities of its individual parts have been also increased. Its total weight was becoming smaller and precisely guessing pre-selected targets was growing. It was very easy to handle the gun, because its overall performance became increasingly acceptable. With the rise of mass production, offers were growing and prices were falling, while the costs - if we exclude the expenditure for ammunition - were almost zero. Indian bows and arrows, due to the accelerated development of destructive techniques looked like children's toys. With the invention of heavy machine guns, thanks to innovations in the quality of firing mechanism, the slow single shots could be replaced by a fast, efficient and effective automatic firearm. Accuracy in automatic shooting has become somewhat smaller. But the (apparent) lack of precision of the new heavy weapons could have been (due to "compression of time and space") easily replaced. A large number of targets could be achieved in a very short time intervals, from great distances, even at very low or any kind of visibility. These technical innovations, combined with the advancement and improvement of optics and target devices, enabled the representatives of the so-called "civilization" to shoot several thousand grains of lethal fire, in a single stroke of the index finger, for a very short time. The outcome of the modernist, industrial, scientific and technological project of the violent act of "civilizing people without literacy," as we know it was fascinating. Unfortunately, most of the Indians and other tribes, who numbered several million people were brutally killed, or died from the disease. Some researchers consider the whole enterprise of "forced civilizing" to be a genocide. Nearly complete, the social, cultural and civilizational conditioned disappearance of the Indians the extermination of the native population - is evidence of crimes against humanity. The crimes were committed under the (intractable) back of civilization conquest of capitalism where the victims were Indians. Daniel J. Boorstin, in this context, spoke of "black holes in American legal history" (Daniel J. Boorstin, 1958).

Photographs of an Amazonian tribe, surrounded by dense trees, were taken from the plane in the late $11^{\text {th }}$ month of 2011 year, on the border between Brazil and Peru are rare evidence that the indigenous tribes (yet) exist. Such groups of several hundred natives never had contact with the so-called advanced and civilized rest of the world. (The advanced world has been called the first world for a very long time, where the other was called the rest, just as we see in the example of the last remnants of extinct tribes) They are fragile and susceptible to external stimuli and noise. These groups of survivors testify about the "remnants" of a (for anthropologists, linguists and other scholars) precious agricultural culture. They cultivate native plants, live in harmony with their indigenous culture. What 
threatens them is the danger that comes from colonizers, drug traffickers, infections, armed hunters, fishermen, etc. They are in danger of extinction. From their standpoint, they are the center of the world, and they are objectively situated in a hostile environment. This is an example among many other examples that might encourage wider thinking. It is necessary to ask about the historical and civilizational responsibility of those who have the power. The responsibility is always given to those who have the power to divide people between "us" and "them" or "other". Although the majority of us has not yet accepted it, a global identity that is identity of species - has been created at the moment when our ancestors started walking upright. Demagogues who created the state and established empires sought to justify its rule by claiming that people living outside their borders are completely different from those who live inside. Today, indigenous peoples are not so scarce as we often think. According to the United Nations, they make five per cent of the world's population, which is three hundred million people. Anthropologist Darrell Posey said, for example, that the Kayapo Indian tribe in the south of Amazonia developed agricultural system that allows them to survive in places where the growing of crops is extremely difficult. This tribe has grown sweet potato resistant to fire, which takes nutrients from naturally burned stumps, and the main crop, which produces its own pesticide, and weeds out while living in symbiosis with a species of ants. Survival of the tribe depends on subtle understanding of the microclimate and the relationships between animals and plants. Unlike almost all modern farmers in the Amazon, they improve the soil and expand forest cover by planting useful trees in the savannah. Their techniques are coded in their songs and stories and the concepts that are difficult to translate into other languages. Their language and self-worth are threatened, which is one thing that most indigenous peoples share. In this case it is because of the economic globalization, political oppression, and because other Brazilians took over the natural resources. This is not only putting the survival of their traditional agriculture at risk, but also the ecosystems in which they live (George Monbiot, 2003). It is also an example of how diversity and universality are always in conflict. The issue is that this conflict can be solved without having to establish something like a responsible global parliament, which would protect the rights of diversity. Corporations are generally governed by their own greed without limits. They are not primarily interested in universal human rights of different individuals, different communities and even entire regions and continents, unless they can earn more in these areas. The capitalists, by definition, create favorable strategic business opportunities in every inch of the planet. It is realistic to expect that the greedy capitalist corporations, in the name of global prosperity, growth and development, could find excuses to destroy the habitats of many aboriginal cultures and underdeveloped regions, in the future as well unless they are stopped. The objectives are the same everywhere: to impose its own rules, to improve and enhance own business activities, to encourage full privatization and entrepreneurship, expand markets, create a favorable business environment, improve the balance of payments, avoid taxes on international financial transactions, to grab the cheapest resources and so on. Let us go back to the example with the recently recorded Amazon tribes: "What is happening in the world is a crime against nature, various tribes and fauna, and it proves how we, the so-called civilized people, treat the world in which we live", said recently a representative of the Survival International organization, which helps tribal communities around the world. Lots of evidence is pointing to the fact that what is called globalization generally operates as a 
complex, controversial and ambiguous semantic expression. The controversies and wars were fought because of the implications of these meanings. "Coups, wars, and massacres were happening in order to maintain regimes of inclined corporations and have never been considered crimes of capitalism, but have been written off as too much exaggeration of eager dictator" (Klein, 2007). Nicholas Ostler, in his interesting book Empires of the Word, says: "We can already notice that the flourishing of creationist views, and the prophetic interpretation of some ancient Christian texts, comes from the very heart of the richest and most developed countries of the English-speaking world. If the powerful people within the United States, which today represent the most productive source of information and scientific knowledge, at some point decide to exert pressure on its independent intelligence, it is quite possible that some other parts of the world decide to start their scientific knowledge to keep the veil of their own language "(Nicholas Ostler, 2005). Medical sociologists can assist in determining the social basis of many diseases. Along with other scientists, they study the social aspects of health and illness, social functions of health organizations and institutions, relationships between health care system and other social systems, social behavior of health workers and users of health care, and patterns of health services (William Cockerham, 1995. Medical Sociology, Englewood Cliffs, NJ: Prentice-Hall.) As a specialization, medical sociology consists of special knowledge by which health and illness are placed in the social, cultural and behavioral context. The Medical sociology consists of describing, explaining, and theories about the distribution of disease among different population groups, behaviours or activities undertaken by individuals in order to maintain, improve or re-establish health, or to adjust to sickness or disability better; attitudes and beliefs about health, illness, and the providers of medical care and medical organizations, medical professions and the professions of the organization, financing and providing medical services, medicine as a social institution and its relationship to other social institutions, cultural values and social responsibility towards health, illness, disability, and the role of social factors in the etiology of disease, particularly functional and emotional disorders and those that are now called stress-induced diseases (Letica Slaven, Medical Sociology, 2003). Sociology of medicine is dealing with medicine and health care as subsystems (social institutions) of the global social system, for instance the study of basic principles and laws of action and behavior of their participants. On 11th September - as formulated by Eriksen - with one stone, the world has been thrown into an uncomfortable and paranoid time in a war without front lines, a conflict without limitations, with a clear beginning, but with an uncertain end. Cues for the globalization of the 90's were the openness, freedom of flight, internet and aircraft traffic on the increase. Cues for the current ten years of globalization are AIDS, threat, control and the police state. We could cite various examples of decade-long effects of U.S. foreign policy but it has already been done and nothing is accomplished. This policy is reflected in technology superior demonstrations of destructive power of smart bombs, and the global weakness of the human mind to stop this kind of destruction, opposes it. It is therefore worth quoting Eriksen when he writes: "All the intellectuals who do not want to be idiots when it comes to a scenario of conflict between" the West "and" Islam ", must now direct the main priority towards the strategy, which reduces the mutual enemy forces" (Thomas Hylland Eriksen, 2002). If we are to understand suicide terrorism, we must carefully examine the wider socio-political context in which it occurs. A series of social, economic, media and other factors, some are unknown 
and many others are well known, when put together create an environment where suicidal terrorists arise. In his book, through the use of the extensive philosophical literature, Stuart Sim has found a common ground for (1) historic fundamentalism, (2) market fundamentalism, (3) political fundamentalism, (4) religious fundamentalism (5) nationalist fundamentalism and (6) fundamentalism in general (as a quest for purity of thought and deed). The common basis of all these forms of fundamentalism (regardless of whether it is the market or religious fundamentalism) is a fundamentalist mentality. Here is a quote that explains the spiritual poverty of companies, when it becomes trapped by fundamentalism: "We live in a fundamentalist world because fundamentalists have such a strong impact on so many of our institutions - religious, political and economic. I am not saying that there is a global conspiracy of different kinds of fundamentalism. Fundamentalists of one area are not necessarily in agreement with fundamentalists of another area - turbulent, mutual disagreement is often likely to occur. What is particularly evident in the field of religion - is that Christian fundamentalists reject the claims of Islamic fundamentalists and vice versa. Each side claims that only they "posses the truth," which was discovered only, solely and exclusively by their prophet. In this part of faith there is no discord - by definition, monotheism cannot stand the rivalry... Religious fundamentalism is exclusive by nature you are either within the circle of devoted believers, or you're against it" (S. Sim, 2004). It is more or less the same with market fundamentalism when it is in charge of the world's economic, political and educational institutions - as it happened after 1989. Market fundamentalism was a thoroughly documented phenomenon in a world civilization (George Soros invented the term). However, some commentators see the International Monetary Fund and World Bank to be a threat to the world peace and harmony. According to Sim's observation, an Islamic scholar Akbar S. Ahmed was one of the first to draw attention to the negative effects of the policy of the IMF and World Bank toward the Third World countries. However, it is not particularly important who it was among the scientists that drew attention to what many other people noticed themselves. Today there are many who rightly speak of market fundamentalism which appears to be a dangerous catalyst for other fundamentalisms. It is possible to specify a number of examples of the negative consequences of market fundamentalism (Africa, Russia, Southeast Asia, Argentina and so on), which all witness and point at what can happen when the free market economy (which, in the end, has not even been implemented by some of the most developed countries that came up with this policy in the first place and were imposing it on others), without any alternative, is imposing itself to the states which lack the necessary social and political structures that are essential for the implementation of this program.

\section{References}

Appadurai, Arjun (2006) Fear of Small Numbers: An Essay on the Geography of Anger, Duke University Press

Aronowitz, Stanley (1988) Science As Power: Doscourse and ideology in Modern Society, Macmillan Press

Aronowitz, Stanley (2000) The Knowledge Factory, Dismantling the Corporate University and Creating True Higher Learning, Beacon Press

Badiou, Alain (2003) Saint Paul: The Foundation of Universalism, Stanford University Press 
Baudrillard, Jean (2002) L' esprit du terrorisme, Edition, Galilée, Paris

Baudrillard, Jean (2004) La pacte de lucidite ou l'intelligence du mal, Editions, Galilée, Paris

Bauman, Zygmunt (2000) Liquid Modernity, Cambridge Polity Press

Beck, Ulrich (1999) What is Globalization? Cambridge, Polity Press

Beck, Ulrich (2007). Weltrisikogesellschaftt: Auf der Suche nach der verlorenen Sicherheit, Suhrkamp, Verlag, Frankfurt am Main

Berberoglu, Berc (2003) Globalization of Capital and the Nation-State, Lanham, Boulder, Rowman \& Littlefield

Berberoglu, Berc (2010) Globalization in the 21st Century: Lobor, Capital and the State an a World Scale, Palgrave, Macmillan

Bhagwaty, Jagdish (2004) In Defense of Globalization, Oxford University Press, Inc.

Bidet, Jacques (1999) Théorie générale: Theorie du droit, de l'économie et de la politique, Presses Universitaires de France

Boorstin, J. Daniel (1958) The Americans, The Colonial Experience, Random House Publishing Group

Bourdieu, P. (2000). Sur La télévision, suivi de l' emprise du journalisme, ISBN-13: 978ID86288396, Clio, Beograd

Brzezinski, Zbigniew (1997) The Grand Chessboard: American Primacy and Its Geostrategic Imperatives, Basic Books, New York

Brzezinski, Zbigniew (2004) The Choice: Global Domination or Global Leadership, Basic Books, New York

Burbach Roger, Nanez Orlando and Kagarlitsky Boris (1997) Globalization and its Discontens: The Rise of Postmodern Socialism. London and Chicago

Callinicos, A. T. (2009). Against The Third Way: An Anty-Capitalist Critique, ISBN, 953-316064-7, Jesenski i Turk, Zagreb

Castells, M. (2003). The Information Age: Economy, Society and Culture, Volume 3, The End of Millennium, ISBN, 953-212-000-9, Golden marketing, Zagreb

Chesnais, F. (2002). In: Soomes-nous sortis du capitalisme industriel?, (Ed.) Carlo Vercellone, La Dispute, Paris

Chomsky, Noam (2003) Hegemony or Survival: America's Quest for Global Dominance, Published by arrangement with Henry Holt and Company, LLC.

Chossudovsky, M. (2008). The Globalization of Poverty and the New World Order, ISBN, 978-953-6460-83-0, Prometej, Zagreb

Coady Tony and Michael O'Keefe (2002) Terrorism and Justice: Moral Argument in a Threatened World, Melbourne University Press

Common Michael and Stagl Sigrid (2005) Ecological Economisc: An Introduction, Cambridge University Press

Corsani, A. (2002) In: Soomes-nous sortis du capitalisme industriel?, (Ed.) Carlo Vercellone, La Dispute, Paris

Crouch, Colin (2003) Postdemocrazia, Roma-Bari

Deaglio Mario, Giuseppe Monateri, Caffarena Anna (2004) La globalizzatione dimezzata, Guerini e Associati

Debord, Guy (1992) La Société du Spectacle, Éditions Gallimard, Paris

Delić, Zlatan (2011) Brightness and Austerity of the Globalization Theory: The Ideological Foundations of Cognitive Capitalism, in Piotr Pachura, ed. (2011) The Systemic Dimension of Globalization, InTech open Access Publisher 
Derek Bok (2003) Universities in the Marketplace: The Commercialization of Higher Education, Princeton University Press

Derrida, J. (2000) L' avenir de la profesion ou l' université sans condition (grâce aux "Humanités" ce qui pourrait avoir lieu demain)

Derrida, J. (2003) Voyous (Deux essais sur la raison), Editions Galilée, Paris

Drucker, F. Peter (1993) Post-Capitalist Society, by Peter F. Drucker

Dubiel, Helmut \& Motzkin, Gabriel (2004) (eds.) The Lesser Evil - Moral Approaches to Genocide Practices, Routledge, London \& New York

Edvinsson, Leif (2003) Corporate Longitude: Navigating the Knowledge Economy, BookHouse Publishing Sweden AB, of Grevgaten 20 S-114 53 Stockholm, Sweden

Eisenstadt, Shmuel N. (1999) Fundamentalism, Sectarianism, and Revolution: The Jacobin Dimension of Modernity, Cambridge University Press

Featherstone, Mike (2007) Consumer Culture and Postmodernism, Sage, London

Finkelstein, G. Norman (2001) The Holocaust Industry: Reflections on the Exploitation of Jewish Suffering, Verso, London

Foer, Franklin (2005) How Soccer Explains the World: An Unlikely theory of Globalization, HarperCollins Publishers

Fulbright, William (1996) The Arrogance of Power, by J. William Fulbright

Furedi, Frank (2005) Politics of Fear: Beyond Left and Right, Continuum International Publishing Group Ltd., London

Giddens, Anthony (2007) Europe in the Global Age, London

Goodman, Amy and David Goodman (2004) The Exception to the Rulers: Exposing Oily Politicians, War Profiteers, and the Media That Love Them, Published by Hyperion, New York

Guellec, D. (2002) L' émergence d' une économie fondée sur le savoir, in J. -P. Touffut (ed), Institutions et innovation: de la recherche aux sysstèmes sociaux d'innovation, Albin Michel, Paris

Gunjevic, Boris (2009). The virtue of Empire between the capital and terror, in Philosophical research, Vol 29. pp. 63-74. Zagreb

Habermas, Jürgen (2004) Der gespaltene Westen: Kleine Politische Schriften X, Suhrkamp Verlag Frankfurt am Main

Habermas, Jürgen (2008) Ach, Europa: Kleine Politische Schriften XI (Suhrkamp), Frankfurt am Main

Ha-Joon Chang (2002). Kicking Away the Ladder: Development Strategy in Historical Perspective, Anthem Press, London,

Haller, Gret (2002) Die Grenzen der Solidarität: Europa und USA im Umgang mit Staat, Nation und Religion, Aufbau Taschenbuch Verlag, Berlin

Hardt, M. \& Negri, A. (2003). Empire, ISBN, 953-98699-2-7, Multimedijalni institut, Arkzin, Zagreb

Harvey, David (2005) A Brief History of Neoliberalism, Oxford University Press, New York Held, D. and McGrew, A. (2002) Globalization/Anti-Globalization, Polity Press, Cambridge Hobsbawm, Eric (2007) Globalisation, Democracy and Terrorism, Litlle, Brown, London

Howitt, P. (1996) The implications of knowledge-based growth for micro-economic policies, University of Calgary Press, Calgary

Hromadžić, Hajrudin (2008) Consumerism: The Needs, Lifestyle, Ideology, Jesenski i Turk, Zagreb 
Ingrao, Charles \& Emmert, A. Thomas (2009) Confronting the Yugoslav Controversies: A scholars' Initiative, by Purdue University

Ippolito, Roberto (2004) 2014 Il futuro che ci aspetta, Editore Laterza

Jean-Luc Nancy (2002) La création du monde ou la mondialisation, Galilée, Paris

Kagarlitsky, Boris (1999) , New Realism, New Barbarism, first published by Pluto Press, Ltd. London

Kienzler, Klaus (1996) Der religiöse Fundamentalismus: Christentum, Judentum und Islam, München.

Klein, Naomi (2007) The Shock Doctrine, by Klein Lewis Productions, Ltd.

Letica, Bartol (2010) Age of Accontability: Corporate Social Responsibility in a Time of Global Financial Crisis, Mate, Zagreb

Liessmann, K. P. (2008) Theorie der Unbildung: Die Irrtümer der Wissensgesellschaft,

Literature:

Luhmann, Niklas (1991) Die Wissenschaft der Gesellschaft, Suhrkamp Verlag, Frankfurt am Main

Maalouf, Amin (1998) Les Identitès meurtrierès, Éditions Graset \& Fasquelle

Marija Geiger Zeman and Zdenko Zeman (2011) Introduction to Sociology (Sustainable) Communities, Ivo Pilar, Zagreb

Marvin, Perry (1993) Intellectual History of Modern Europe, Houghton Mifflin

Masudul Alam Choudhury and Lubna Sarwath Mohammad (2011) Sustainability by Interrrelating Science, Society and Economy in Embedded Political economy epistemological Approach, in Piotr Pachura (ed. 2011), The Systemic Dimension of Globalization, Published by InTech

McQuillan, Martin (2001-2-28) Textual Activism: Deconstruction After '9/11' (Routlege), ISBN 041593687X -EAN 978041593687

Monbiot, George (2004). The Age of Consent: A manifesto for a new world order, by HarperCollins

Mouhoud, M. (2002) In: Soomes-nous sortis du capitalisme industriel?, (Ed.) Carlo Vercellone, La Dispute, Paris

Muller, Jan- Werner (2002) Introduction: the power of memory, the memory of power and the power over memory, in Muller, Jean- Werner ed. (2002), Memory and Power in Post-War Europe - Studies in the Presence of the Past, Cambridge University Press

Negri, Antonio \& Hardt, Michael (2000) Empire, Cambridge, Massachusetts, London

Nelson-Jones, Richard (2004) Cognitive Humanistic Therapy, London, SAGA, Publications

Neumann, I. B. (2009). Mening, materialitet, makt: en innføring i diskursanalize, Alexandria Press

Ohmae, K. (2007). The Next Global stage: Challenges and Opportunities in Our Borderless World, ISBN, 978-953-246-032-2, Mate, Zagreb

Ortayli, Ilber (2009) Different understanding of the Ottomans (Osmanliyi yeniden keşfetmek), Copyright by Connectum, Sarajevo

Ostler, Nicholas (2005) Empires of the World: A Language History of the World, New York, Harper Perennial

Patnam, R. (1993) Making Democracy Work: Civic Traditions in Modern Italy, Princeton University Press

Paulré, B. (2000) De la New Ekonomy au capitalisme cognitif, Multitudes 2, pp. 25-42, Exils Editeur, Paris, 
Rifkin, Jeremy (2004). The European Dream: How Europe's Vision of the Future is Quietly Eclipsing the American Dream, Polity Press, Cambridge. Published by arrangement with Jeremy P. Tarcher, a member of Penguin Group (USA) Inc.

Rifkin, Jeremy (1998) The Biotech Century - Genes are the raw resource for the next century, Jeremy P. Tarcher/Putnam a member of Penguin Putnam Inc., New York

Ritzer, George (1996) The McDonaldization of Society, Sage Publications Company Thousend Oaks, California, USA; Sage publications Ltd. London, United Kingdom

Robertson, R. (1992) Globalisation: Social theory and Global Culture, Sage, London

Rorty, Richard (1989) Contingency, Irony and Solidarity, Cambridge Univesity Press

Rosen, Stenley (1980) The Limits of analysis, New York

Rosenberg, J. (2000) The Follies of Globalisation Theory, Meard Street, London, USA: 180 Varick Street, New York

Sardar, Ziauddin \& Borin, Van Loon (2001) Introducing Science, Cambridge

Sardar, Ziauddin \& Davies Merryl Wyn (2002) Whu do People Hate America? Icon Books, U.K.

Sardar, Ziauddin (2008) Reading the Qur'an: The Contemporary Relevance of the Sacret Text of islam, Oxford University Press

Scholte, Jan Aart (2005). Globalization: A Critical Introduction, Second Edition, Revised and Updated, Palgrave, Macmillan

Semprini, Andrea (1997) Le multiculturalisme, Paris, Presses Universitaires de France

Sen, Amartya Kumar (2006) Identity and Violence: The Illusion of Destiny, W. W. Norton \& Company

Sheila C. Dow (2003) Economic Methodology an Inquiry, Oxford University Press Inc., New York

Shiva, Vandana (2002) Water Wars: Privatisation, Pollution and Profit, Cambridge

Shumar, W. (1997) College for Sale: A Critique of the Commodification of Higher Education, Falmer Press, London

Sim, Stuart (2004) Fundamentalist World: The New Dark Age of Dogma, Publisher, Icon Books

Snower, J. D. (2009). Four mega-dangers international financial markets face, In: The First Global Financial Crisis of the 21th Century, pp. 107-109, ISBN 978-953-6808-17-5, Novum, Zagreb,

Steger, B. Manfred (2003) Globalisation, Oxford University Press Inc., New York

Stiglitz, E. Joseph (2007) Making Globalization Work: The Next Steps to Global Justice, Publisher, Penguin

Swedberg, Richard (2005) New Development in Economic Sociology, Volume I, Published by Edward Elgar

Tabelini, G. (2009) Why did bank supervision fail?, In: Felton, A. \& Reinhart, The First Global Financial Crisis of the 21th Century, pp. 45-48, ISBN 978-953-6808-17-5, Novum, Zagreb,

Todaro, P. Michael \& Smith, C. Stephen (2006) Economic Development - ninth edition

Tonkiss, F. (2006) Contemporary Economic Sociology: Globalisation, Production, Inequality), Routledge, London and New York

Walia, Shelley (2001) Edward Said and the Writing of History, Icon Books, Ltd, Cambridge Wallerstein, Immanuel (2003) The Decline of American Power, The New Press, NewYork London 
Walton, P. \& Young, J. (ed.) (1998) The New Criminology Revisited, Macmillian, Basingstoke

Zimbalist, A. (1999) Unpaid Professionals: Commercialism and Conflict in Big-Time College Sports, Princeton University Press

Zinn, Howard (2003) A people's History of the United States - 1492- Present, New York: Harper Collins

Zizek, Slavoj (2004) Iraq: The Borrowed Kettle, First Published by Verso 2004 


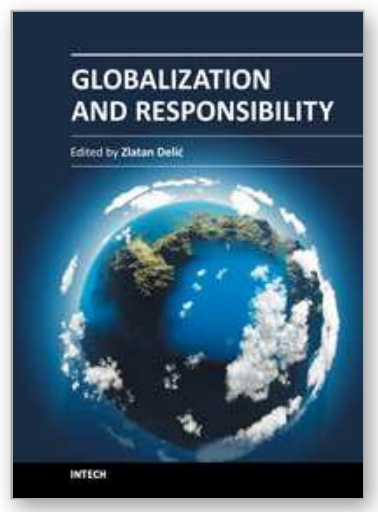

\author{
Globalization and Responsibility \\ Edited by Dr. Zlatan Delic
}

ISBN 978-953-51-0655-5

Hard cover, 166 pages

Publisher InTech

Published online 29, June, 2012

Published in print edition June, 2012

The book "Globalization and Responsibility" consists of 8 chapters. The chapters in the book offer a decentered and dynamic terminology. They show that globalization consists of not only an objective process, but also of a lot of statements that define, describe and analyze the different experiences of the process. The chapters are written by authors and researchers from different academic disciplines, cultures and social contexts, therefore different experiences and scientific analyses on the consequences of globalization have been unified, starting from the multicultural and social epistemology to ethics of responsibility. Each chapter can be read separately, but in a complex, interconnected global universe of intertextuality of our world.

\title{
How to reference
}

In order to correctly reference this scholarly work, feel free to copy and paste the following:

Zlatan Delić (2012). The Consequences of Globalization and Responsibilities: Challenges of Sustaining Development, Globalization and Responsibility, Dr. Zlatan Delic (Ed.), ISBN: 978-953-51-0655-5, InTech, Available from: http://www.intechopen.com/books/globalization-and-responsibility/the-consequences-ofglobalization-and-responsibilities-challenges-of-sustaining-development

\section{INTECH}

open science | open minds

\section{InTech Europe}

University Campus STeP Ri

Slavka Krautzeka 83/A

51000 Rijeka, Croatia

Phone: +385 (51) 770447

Fax: +385 (51) 686166

www.intechopen.com

\section{InTech China}

Unit 405, Office Block, Hotel Equatorial Shanghai

No.65, Yan An Road (West), Shanghai, 200040, China

中国上海市延安西路65号上海国际贵都大饭店办公楼405单元

Phone: +86-21-62489820

Fax: +86-21-62489821 
(C) 2012 The Author(s). Licensee IntechOpen. This is an open access article distributed under the terms of the Creative Commons Attribution 3.0 License, which permits unrestricted use, distribution, and reproduction in any medium, provided the original work is properly cited. 